\title{
COP26 Futures We Want - Brazil Country Profile
}

The purpose of this country profile was to provide an evidence base to inform the production of Net Zero Future visions. A consolidated version of material contained here was used as stimulus for in-country workshops and creative translational approaches that will develop a plausible vision for each country. This document provides a selection of relevant evidence for the sectors and themes identified through the scoping exercise.

\section{Part A: Executive Summary}

This country profile for Brazil has been developed with the input from in-country academic experts, including Dr. Roberto Luís de Melo Monte-Mór (Federal University of Minas Gerais), Dr. Jakob Sparn, Dr. Olinda Canhoto (Centro de Biotecnologia Amazônia) and Dr. Carlos Lamarão (Federal University of Amazonas), in the context of the BEIS COP26 Futures We Want project. It provides a review of the available evidence on the risks, solutions and opportunities for Brazil and Brazilian society to contribute towards a global transition to a net zero future that is inclusive, resilient and desirable by all.

Brazil's most recent commitment to the Paris Agreement is a $37 \%$ reduction of GHG emissions by 2025 and a $43 \%$ reduction by 2030, using 2005 as a baseline. As part of this commitment, the government has initiated sectoral approaches to reduce emissions and support climate change adaptation and mitigation measures. Brazil is characterized by immense environmental and cultural diversity as well as extreme economic and social inequality. These characteristics play an important role in the economic context of the country as well as presents challenges and opportunities for a net zero future.

Agriculture and land-use change are intimately connected sectors that are both at the forefront of combatting GHG emissions and the economic vitality in Brazil. Therefore, these two sectors provide the key to a net zero future. At the heart of the relationship between these two sectors is deforestation, which is the country's largest emitter of GHG emissions and driven by agriculture and livestock production. Small and medium family farms contribute towards the GHG emissions profile but also provide solutions in the form of agroecology, ecosystem services and nature-based solutions. Solutions can also be found in the Amazon region, where deforestation is most prevalent and its forests serve as the world's largest terrestrial carbon sink. Proposals in the Amazon include the development of a bioeconomy, where Indigenous groups and traditional peoples benefit from the tremendous biodiversity of the region.

Brazil's natural endowment provides opportunities and challenges for a net zero future in the areas of energy and physical infrastructure. $20 \%$ of the world's freshwater is found within Brazilian territory which is harnessed for hydroelectric power that contributes to $65 \%$ of the country's electricity generation. Abundant winds and sun in the semi-arid Northeast of the country also provide opportunities for wind and solar. All energy sources in the country have the potential to be more inclusive; hydroelectric sources could be more responsive to the displacement of Indigenous and traditional 
peoples, and wind and solar could be more inclusive by providing employment opportunities for the poorest region of the country. Brazil's vast territory also presents challenges for transport. A majority of all transport in the country relies on roads or waterways (the latter in the Amazon Basin). The country has an extremely limited rail network and, where one does exist, it is almost exclusively for cargo. Roads and water transport are vulnerable to climate risks in addition to the already hostile tropical rains and steep landscapes present in much of the country.

Regional diversity in Brazil also contributes towards the challenges and opportunities for a net zero future. Each of the distinct climates and biomes in the country are related. Climate risks and vulnerabilities, as well as efforts to mitigate, adapt and build resilience to climate change, should consider this diversity. Over $60 \%$ of the country's population lives in coastal areas, which presents significant vulnerabilities based on future projections of sea level rise. However, urban inequalities in wealth and infrastructure mean that not all climate risks will be shared equally. Therefore, a focus on economic inclusion and participation in a net zero future should be considered. Inequalities are even more pronounced in rural areas, and in particular in the rural Northeast region. The Northeast region is also where prolonged droughts have already increased in severity and are predicted to only get worse. Measures such as cisterns and more efficient use of water can help mitigate problems of drought in the region, but longer-term efforts to curb deforestation in the rest of the country could also help improve more regular rainfall patterns.

This country profile includes three main sections: 1. A broad overview of the Brazilian context, including the economy, geography and current GHG emissions profile; 2. Physical climate change scenarios, including risks, adaptation and opportunities. This section will also consolidate risks around the three sectors of agriculture, industry and services. These three sectoral groupings are utilized by the Brazilian government to consider climate risks, economic data and are inclusive of the sectors in the third section of this report; 3 . Development compatible transitions, including risks, mitigation and opportunities. In the third section, there is a focus on the sectors identified by the in-country experts as being more relevant for a net zero future in Brazil. These sectors include: 1. Agriculture and livestock; 2. Land use and natural resources; 3 . Physical infrastructure; 4 . Energy generation; 5 . Circular and social bioeconomy and; 6 . Naturebased solutions.

\section{Part B: Expert Committee Inputs}

\section{Country Context}

\section{1.a Economic Context}

The Brazilian economy has historically relied on the export of raw materials and agricultural commodities. Ever since Portuguese colonialism, there have been a series of booms and busts of commodities based on large-scale production models. This cyclical nature of commodity production has also relied extensively on the social and environmental differences between regions. For example, the 19th century rubber boom in the Amazon region relied largely on a cheap and extensive labor force to 'tap' the rubber trees. ${ }^{1}$ Much of the labor required from tapping came from the Northeast where land inequality and sugarcane production produced an excess labor supply. In 
the Southeast states, such as São Paulo, Rio de Janeiro and Paraná, intensive coffee production degraded soils and increasingly pushed the coffee frontier further inland. Mining has also shaped the unequal benefits of extraction in the country. From gold mining in the 18th century to iron ore extraction today, poor labour standards and low wages fueled mining activities that devastated the environment and indigenous populations. $^{2}$

The Brazilian economy has relied on the country's extensive and diverse territory as well as the regional disparities in development and social inequality. Throughout the 20th century, Brazil has continued to rely on the export of raw materials. Today, the production and extraction of those materials has become much more technologically advanced. In the agricultural and petroleum sector, the Brazilian state has invested in research that has increased productivity and offshore drilling, respectively. During the mid-20th century, these investments helped foster industrialization and positioned Brazil as a Newly Industrialized Country (NIC). However, due to longstanding structural inequalities, increases in labor productivity have not resulted in a more inclusive economy and low consumption and competitiveness has resulted in a slow deindustrialization of the economy.

Over the last two decades, higher global commodity prices resulted in an increase in government revenues that were part of a new wave of social policies aimed at reducing poverty and combatting food insecurity. Notable cases, such as the Bolsa Familia, garnered global attention as an innovative and effective way to finance human development and curb extreme poverty. These actions led to an increase in the middle class and important public investments in energy, education and the environment. One notable achievement was the rapid decrease in deforestation, but that has since started again to increase. In 2009, the Brazilian government pledged to cut the average deforestation rate of $1996-2005$ by $80 \%$ in the target year of 2020 . However, deforestation increased steadily in 2012 and reached a decade-high peak in 2020, missing the target by $182 \%{ }^{3}$. The recent and prolonged financial and political crises over the past five years have led to a stagnation in wages and uncertainty around the public investments in energy, education and the environment. Compounding these problems, there has been a reduction in terms of public financing for education, social welfare, enforcement of deforestation and a commitment to a reduction in GHG emissions since 2016. The data shows that the situation has only worsened under the current presidential administration. Many of the promising trends have reversed in terms of environmental protection (including deforestation ${ }^{4}$ ), economic inclusion and social advancements ${ }^{5}$. 


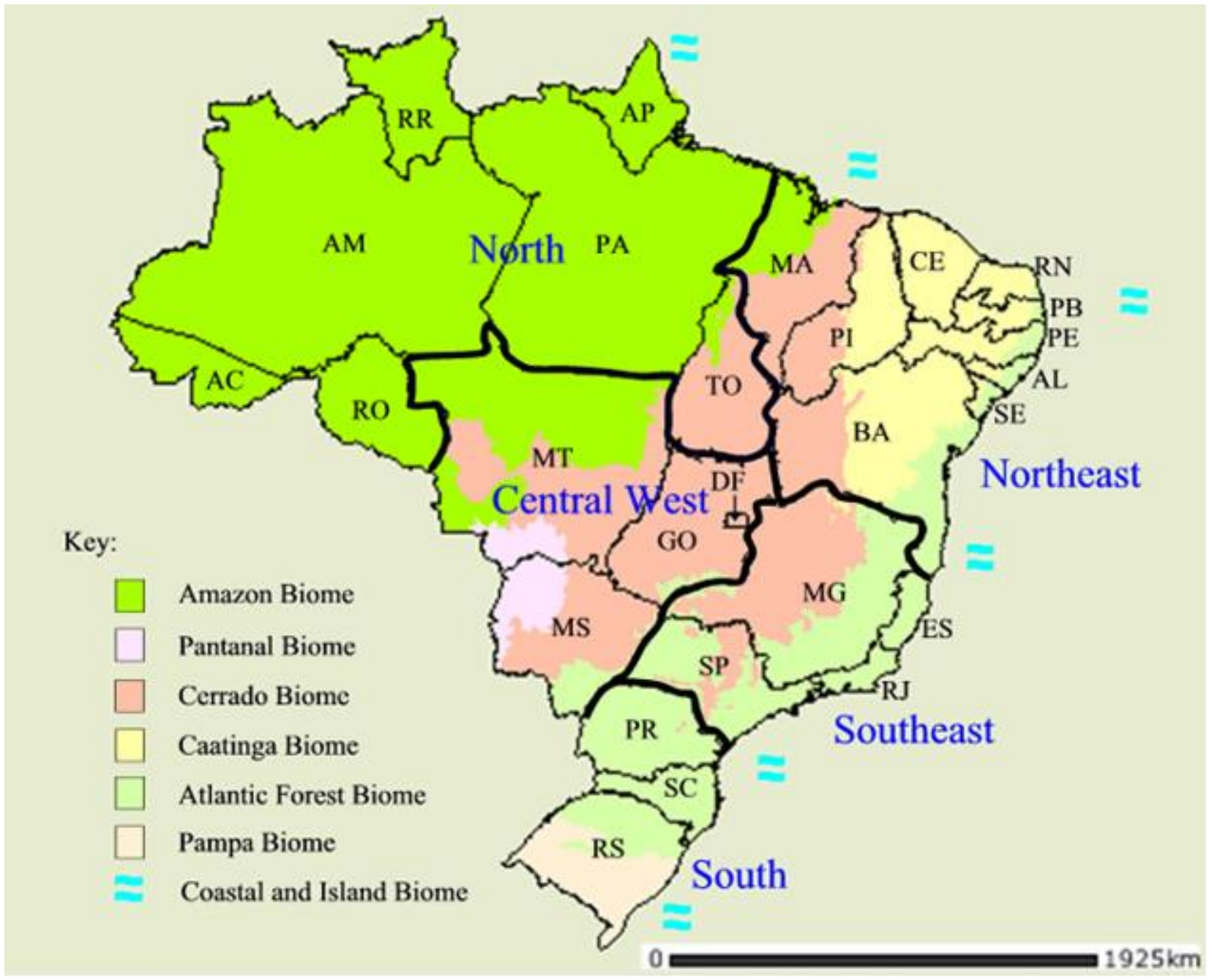

Figure 1: Biomes and Regions of Brazil Figure from: Hargreaves, Peter (2008) "Phytosociology in Brazil" The Americas Journal of Plant Science and Biotechnology 2(2). $\underline{6}$

\section{1.a.i Sectors that contribute most to GDP in Brazil}

The agriculture and livestock sector is the largest contributor to Brazil's economy at just over $26 \%$ of national GDP in 2020. The sector experienced a growth of $6.1 \%$ relative to GDP in $2019 .{ }^{7}$ Industry as a broad category contributes to $17.6 \%$ of GDP, with construction and energy ${ }^{8}$ constituting $5.1 \%$. In the service sector, transport and storage represent $3.7 \%$ of GDP and public services, such as health, education and social security, contribute $15 \%$ to the country's GDP. ${ }^{9}$. In terms of employment, $10.2 \%$ of the population is employed in the agricultural and livestock sector. $20.9 \%$ in industry and $68.9 \%$ in services. ${ }^{10}$.

1.a.ii Sectors that represent growth areas for the country economically (in absolute terms, but also as a proportion of GDP) 
The current economic outlook for Brazil has been hampered by a recent and prolonged economic recession. From 2014 to 2016 the unemployment rate more than doubled and has since remained stagnant. ${ }^{11}$ The effects of COVID-19 then worsened the problem with a contraction of $7 \%$ in GDP in 2020 . However, the sectors that have performed and presented opportunities for additional growth include: agriculture and livestock, oil and gas, aviation and the financial sector. Agriculture has shown positive productivity, economic and export growth since the 1970s and, in 2020 grew by $3 \%$ despite the prolonged economic recession and contraction due to COVID-19.12 The automotive sector has also been growing at around $2 \% / y$ ear due to the country's reliance on car transport for people, goods and services. Consumption of automotive has remained steady, as the $6^{\text {th }}$ largest automotive market in the world, despite declines in domestic automotive manufacturing. ${ }^{13}$ Lastly, Brazil also has an emerging biotechnology sector, primarily related to agriculture and pharmaceuticals, with major multinational and national headquarters in the country that rely on the biodiversity of the country for research and development.

\section{1.a.iii. Major trade-flows (goods and services) in and out of Brazil}

Brazil's exports totalled US $\$ 230$ billion (27th largest in the world), while the country imported a total of US $\$ 177$ billion in goods and services in 2019. The largest exports included soybeans (US\$26.1 billion), crude petroleum (US\$24.3 billion), iron ore (US\$23 billion) corn (US\$7.4 billion) and chemical woodpulp (US\$7.35 billion). The country's exports went mostly to China (US\$63.5 billion), the United States (US $\$ 30.5$ billion), Argentina (US\$9.85 billion), the Netherlands (US\$9.3 billion) and Japan (US\$5.6 billion). Brazil is the world's largest exporter of soybeans, sulphate chemical woodpulp, poultry meat, frozen beef and raw sugar.

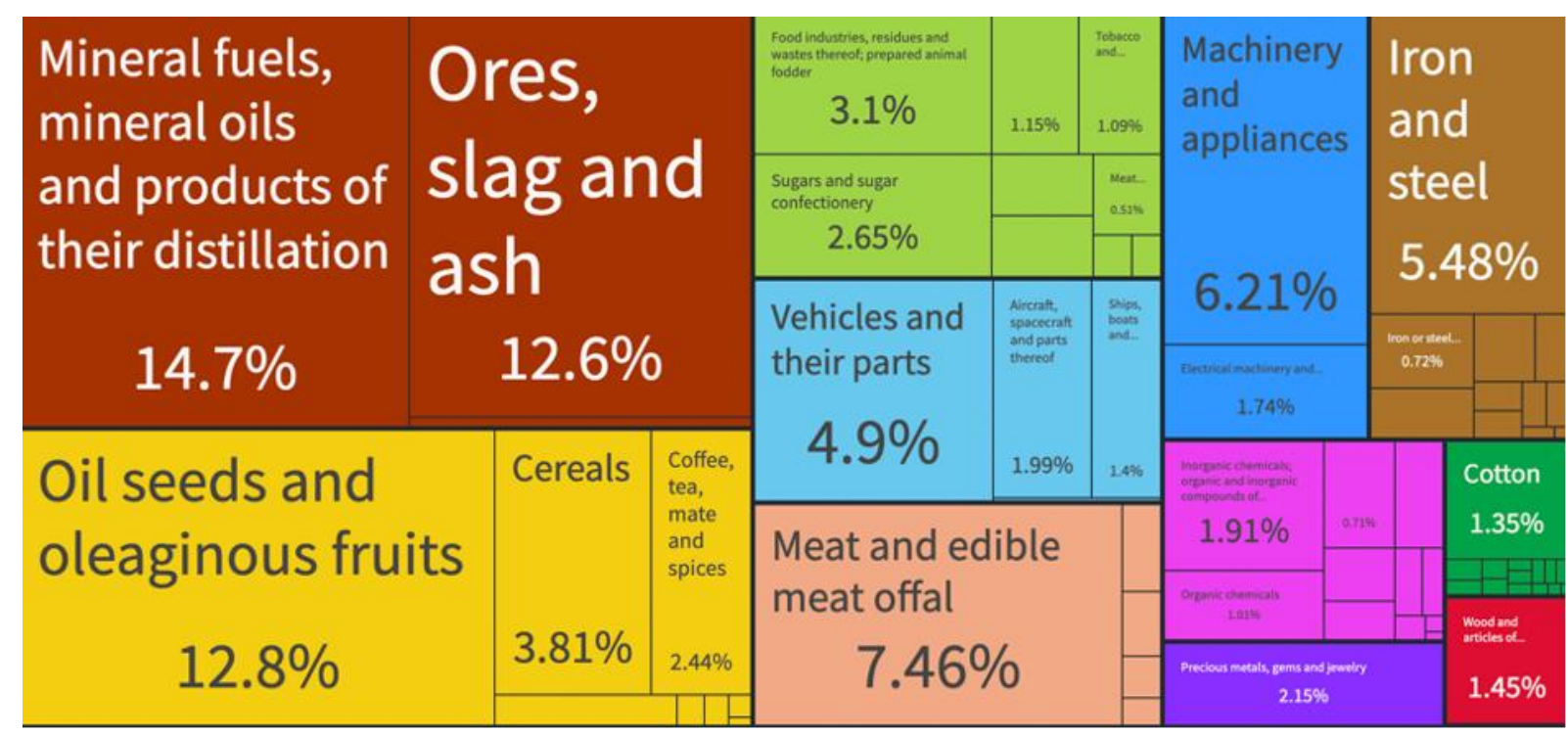

Figure 2: Brazil exports totalled US\$230 billion in 2019 Link 


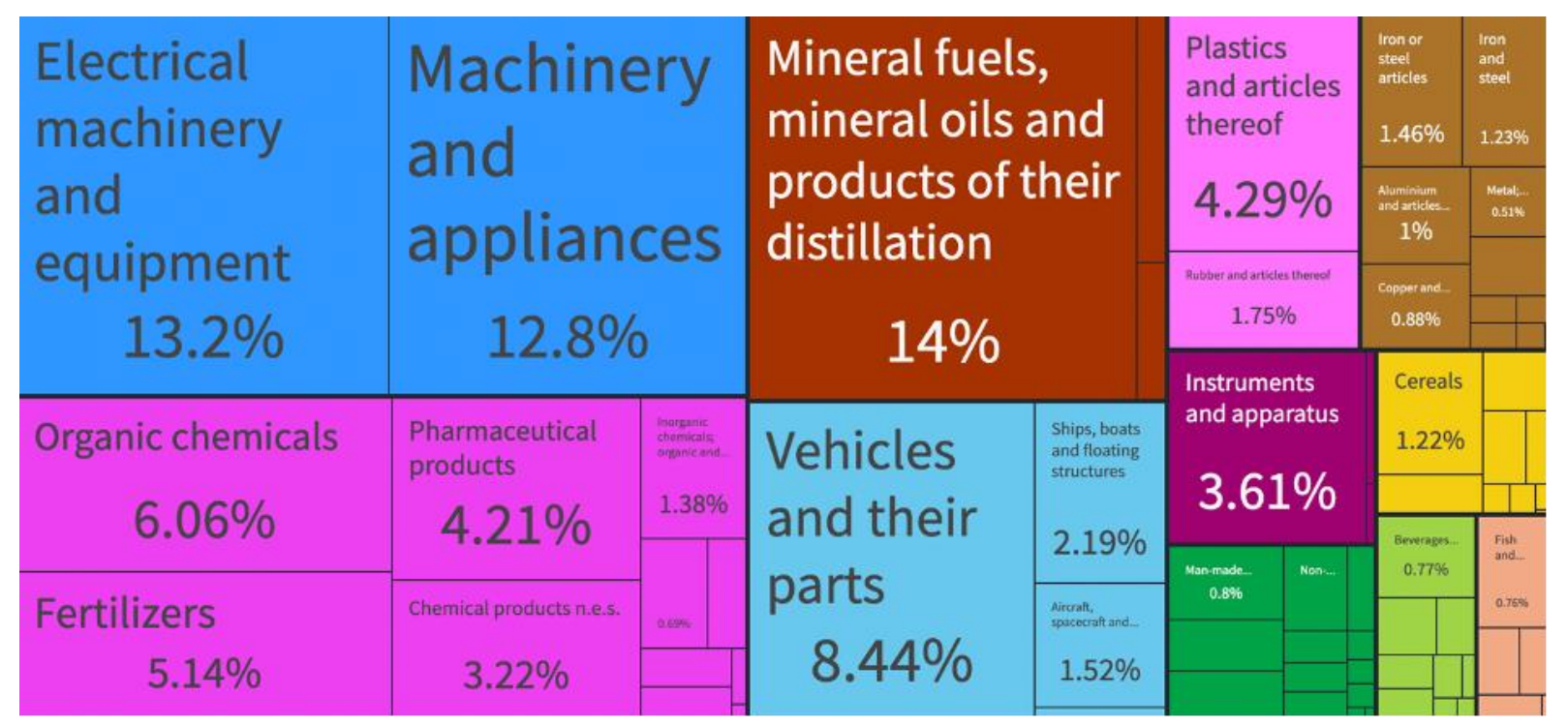

Figure 3: Brazilian Imports Totalled US\$177 billion in 2019 Link

Brazil had a positive trade balance of US $\$ 53$ billion in 2019 . However, exports tend to consist of raw materials and primary goods, whereas imports are largely value-added and manufactured/processed goods. For example, around 10\% of Brazilian exports are crude oil while about $7 \%$ of imports are refined petroleum products. Imports of refined petroleum products have increased since 2016 following the privatization of some of the national refineries. ${ }^{14}$ Chemical products also constitute a major share of total imports, a majority of which are inputs for the agricultural sector that produces primary goods for exports. Lastly, advanced technological products constitute a large share of total imports, which are significant value-added imports and reflective of a potential future development path for Brazil.

\section{1.b Development Context}

\section{1.b.i What are the key development indices for this country?}

Brazil's Human Development Index (HDI) in 2019 was 0.765, which falls in the "high human development category" at 84 out of 189 countries and territories. ${ }^{15}$ Over the past 20 years, Brazil's HDI increased by 24.8 percent from 0.613 to 0.765 . However, the country's diverse regions play a significant role in the inequality of development, and therefore some context should be added to understand Brazil's national HDI. Historically, high inequalities in land tenure have shaped both human development and income inequality..$^{16}$ For example, the Federal District has the country's highest $\mathrm{HDI}$ at 0.824 (around 50 ${ }^{\text {th }}$ globally) whereas the state of Alagoas is the lowest at 0.631 (around $130^{\text {th }}$ globally) (see Figure 4). ${ }^{17}$ Brazil's GINI index, a measure of income inequality, has fallen from 63.3 in 1989 to 53.4 in $2019^{18}$. Despite the drop in inequality, Brazil remains amongst the ten most unequal countries in the world, as measured by the GINI index. It is also one of the most unequal countries in terms of land inequality ${ }^{19}$ and one of the highest concentrations of land ownership in the world. For example, the largest $0.3 \%$ of farms (just under 16,000 ) in Brazil occupy $25 \%$ of all agricultural land and the largest $10 \%$ of farms occupy $73 \%$ of total agricultural land (see figure 5) ${ }^{20}$ In other words, large farms in Brazil are truly massive in scale. They are also the 
primary importers of agricultural inputs and exporters of agricultural commodities. On the other hand, small or 'family' farms ${ }^{21}$ constitute $77 \%$ of total farms but only occupy $23 \%$ of total agricultural land. ${ }^{22}$. Family farms produce mainly for the domestic food market.

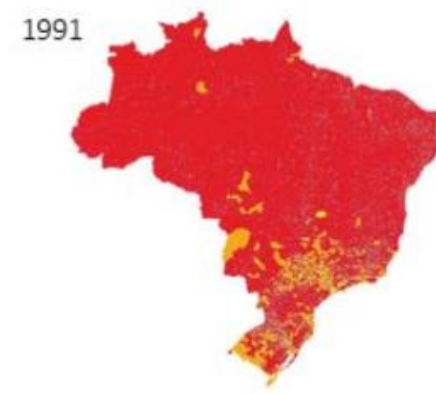

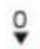

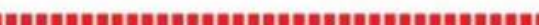
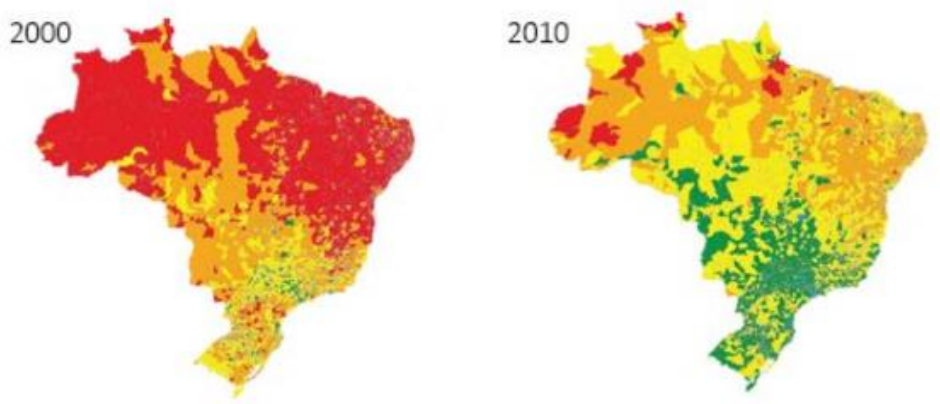

$0,499 \boldsymbol{\nabla}^{0,500} 0,599 \mathbf{v}^{0,600} 0,6990,700 \quad 0,799 \boldsymbol{v}^{0,800}$

Figure 4: Historical Change in Brazil's HDI from 1991-2010 Link

Figure from: Atlas Desenvolvimento Humano no Brasil (Human Development Atlas of Brazil)

$0.3 \%$ largest rural properties concentrates $25 \%$ of private land

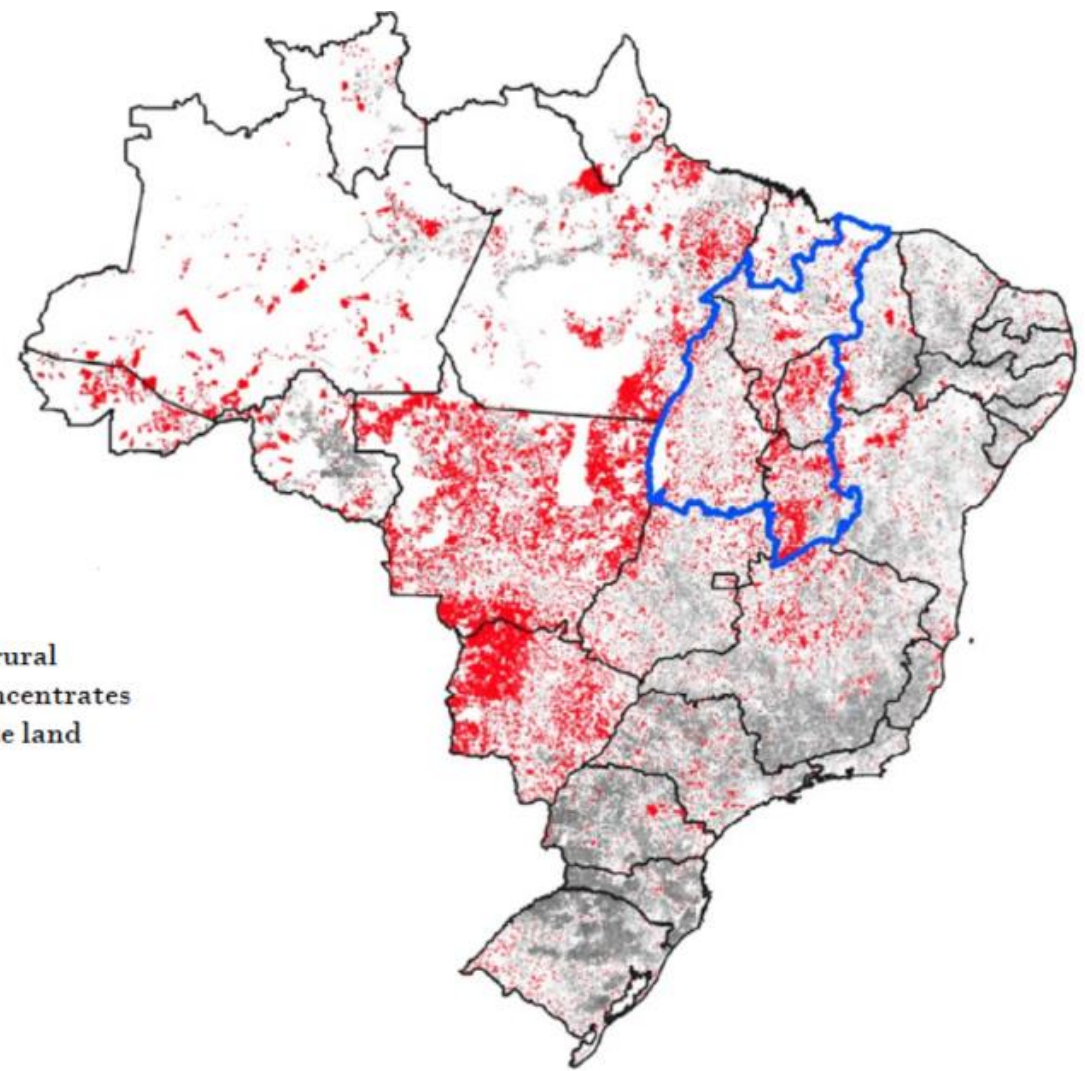

Figure 5: Geographical Distribution of the Largest Properties that Occupy 25\% of Agricultural Land Link

Figure from: WCMC (2020) "Novel Study Maps out the Inequality of Land Distribution and Ownerships in Brazil" Trade, Development and the Environment Hub 


\section{1.b.ii What are the priorities and barriers to enabling sustainable, inclusive and resilient growth in Brazil?}

Brazil has several key priorities for sustainable, inclusive and resilient growth. Some of these priorities vary in importance by region. Combating deforestation remains a priority across all regions. Deforestation declined substantially since 2004 but then started to increase again in $2012^{23}$ (see figure 6). Another priority is to combat social and economic inequality. Brazil remains one of the most unequal countries in terms of income inequality, inequality of land ownership and unequal development between regions. An important facet of inequality is the lack of a quality basic income for all. Lastly, a reduction on the reliance on input-intensive agriculture, and other forms of intensified land use, remains one of the most difficult, if necessary, priorities for a lowcarbon economy.

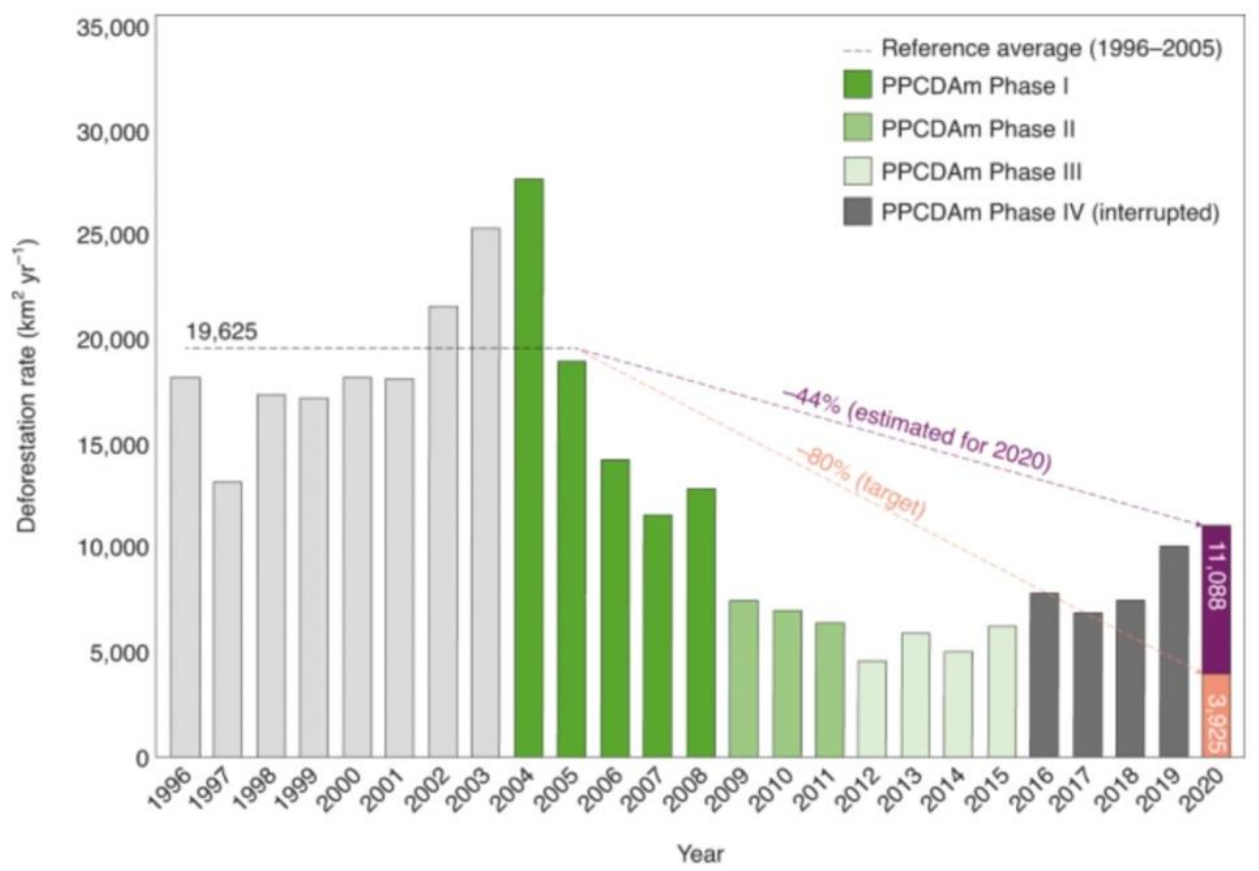

Figure 6: Historical Deforestation Rates in the Amazon, 1996-2020

Figure from: Silva Junior, Celso H.L. et al. (2020) "The Brazilian

Amazon Deforestation rate in 2020 is the Greatest of the Decade" Nature Ecology \& Evolution 5: 144-145.

Barriers for a transition to sustainable, inclusive and resilient growth include: 1) a lack of policy options to counter the economic drivers of land-use change due to agribusiness growth throughout most of the country, but most notably in the biomes of the Amazon, ${ }^{24}$, Cerrado ${ }^{25}$ and Atlantic Forest; ${ }^{2627}$; 2) the effects of climate change pose significant barriers for economic activities, ${ }^{28}$, including agribusiness, ${ }^{29}$, and for policy to have an impact on resilience and sustainable development ${ }^{30}$, which includes basic infrastructure for water and the electric grid; 3 ) high levels of social and economic inequality ${ }^{31}$ remain throughout the country, with the highest levels being in the Northeast and Amazonian regions. ${ }^{32}$ Barriers that are specific to the agricultural sector - the most important for Brazil's economy and a low-carbon future - include: 1) uncertainties around the legalities of deforestation; 2) weak institutional capacity at the 
state level; 3) difficulty of farmers to access credit for investments in low-carbon transitions. ${ }^{33}$. On the second point, there is a diversity of governance at the state level throughout the country. Brazil is a federative republic and the state government can vary widely in the development challenges and opportunities. For example, the state of Amazonas in the North is roughly the same size in area as Western Europe, but with far less economic integration and heavily reliant on rivers for transportation. This context provides serious challenges for governance, including the delivery of human services, enforcement of laws and for an accounting of the tremendous biodiversity and implementing tools to conserve it.

\section{1.c Development compatible greenhouse gas emissions (GHGs)}

\section{1.c.i Current GHG emissions profile for Brazil}

Brazil is one of the world's top 10 GHG emitters.

- Total annual $\mathrm{CO}_{2}$ emissions were 465.72 million tons in 2019 and accounted for just under 1.4 percent of the global total.

- Total annual GHG emissions, including land use change and forestry, were 2.17 billion tons $\mathrm{CO}_{2} \mathrm{e}$ in 2019 , a $9.6 \%$ increase from the 1.98 billion tons $\mathrm{CO}_{2} \mathrm{e}$ emitted in $2018^{34}$, driven by high deforestation in the Amazon.

- Consumption-based $\mathrm{CO}_{2}$ emissions totalled 488.87 tons $\mathrm{CO}_{2}$ (2018)

- Per capita emissions of 2.21 tons $\mathrm{CO}_{2}$ per person (2019, see Figure 7) and GHG emissions of 3.60 tons of $\mathrm{CO}_{2} \mathrm{e}$ per person (2016)

- $\quad$ The Brazilian Amazon, long thought to be a net absorber of $\mathrm{CO}_{2}$, released 16.6 billion tonnes of $\mathrm{CO}_{2}$ while it absorbed 13.9 billion tons from 2010-201935

Brazil's $\mathrm{CO}_{2}$ emissions by fuels increased rapidly in the past 70 years. However, fuelbased emissions have been in decline over the last six years. Oil is the largest contributor, followed by coal, and then gas in terms of total fuel-based $\mathrm{CO}_{2}$ emissions in 2017. The historical trends and recent increases in deforestation in the Amazon are of particular concern. Around $16.4 \%$ of Brazil's GHG emissions, and a net of 295 million tons of net $\mathrm{CO}_{2}$, are due to deforestation and fires occurring in the Amazonian region alone in $2017 .{ }^{36}$. 


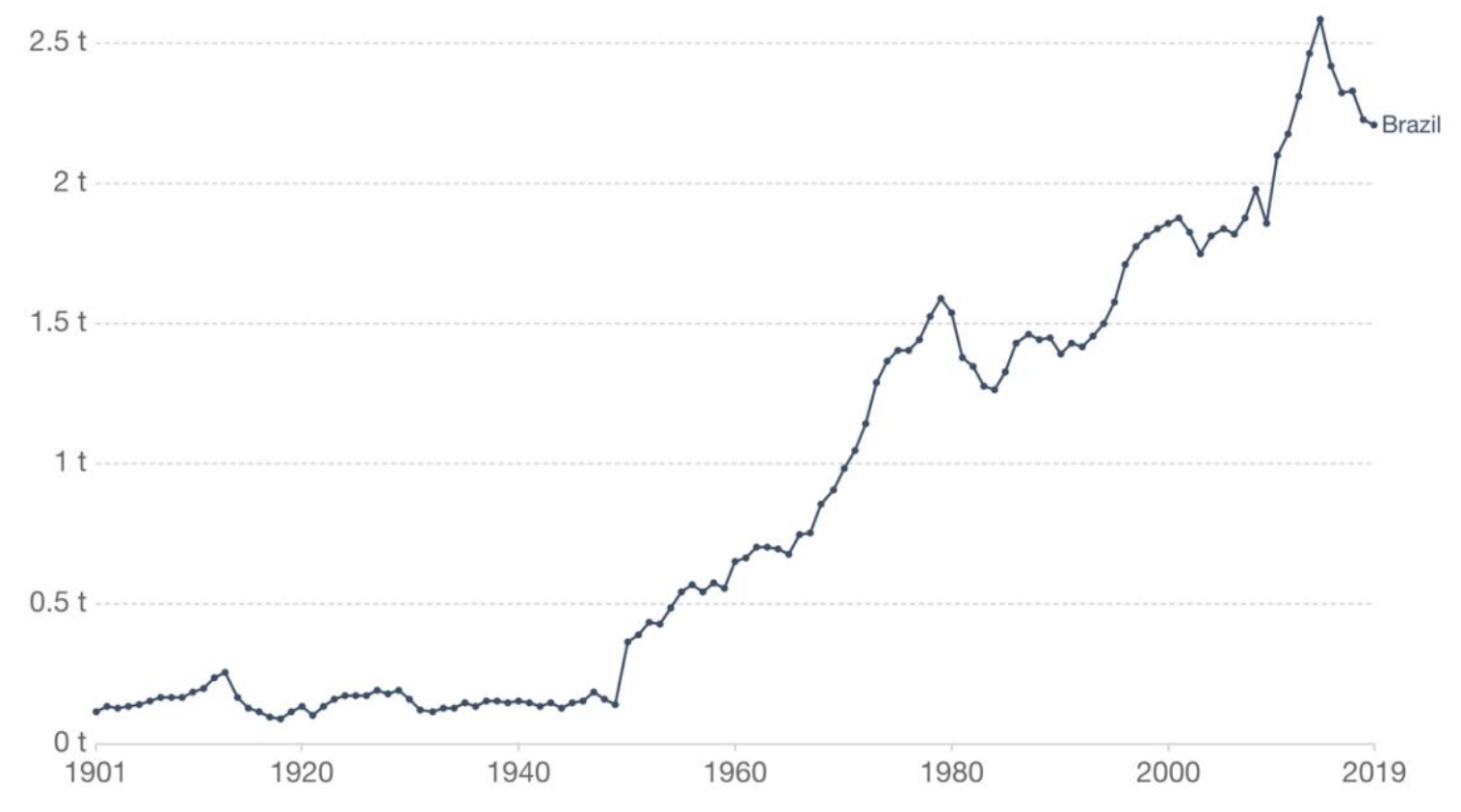

Source: Our World in Data based on the Global Carbon Project; Gapminder \& UN

Note: $\mathrm{CO}_{2}$ emissions are measured on a production basis, meaning they do not correct for emissions embedded in traded goods. OurWorldlnData.org/co2-and-other-greenhouse-gas-emissions/ • CC BY

Figure 7: Per Capita $\mathrm{CO}_{2}$ Emissions for Brazil (1901-2019). Figure from: Our World in Data.

\section{1.c.ii Sector-specific GHG emissions from the sectors which are key for development in this country}

Agriculture is by far the largest GHG emitting sector in Brazil (Figure 8). When breaking down the emissions by methane and nitrous oxide, the sector stands out even more in terms of emissions (see figures 9,10 ). 
Greenhouse gas emissions by sector, Brazil

Breakdown of total greenhouse gas emissions by sector, measured in tonnes of carbon-dioxide equivalents $\left(\mathrm{CO}_{2} \mathrm{e}\right)$. Carbon dioxide equivalents measures the total greenhouse gas potential of the full combination of gases, weighted by their relative warming impacts.

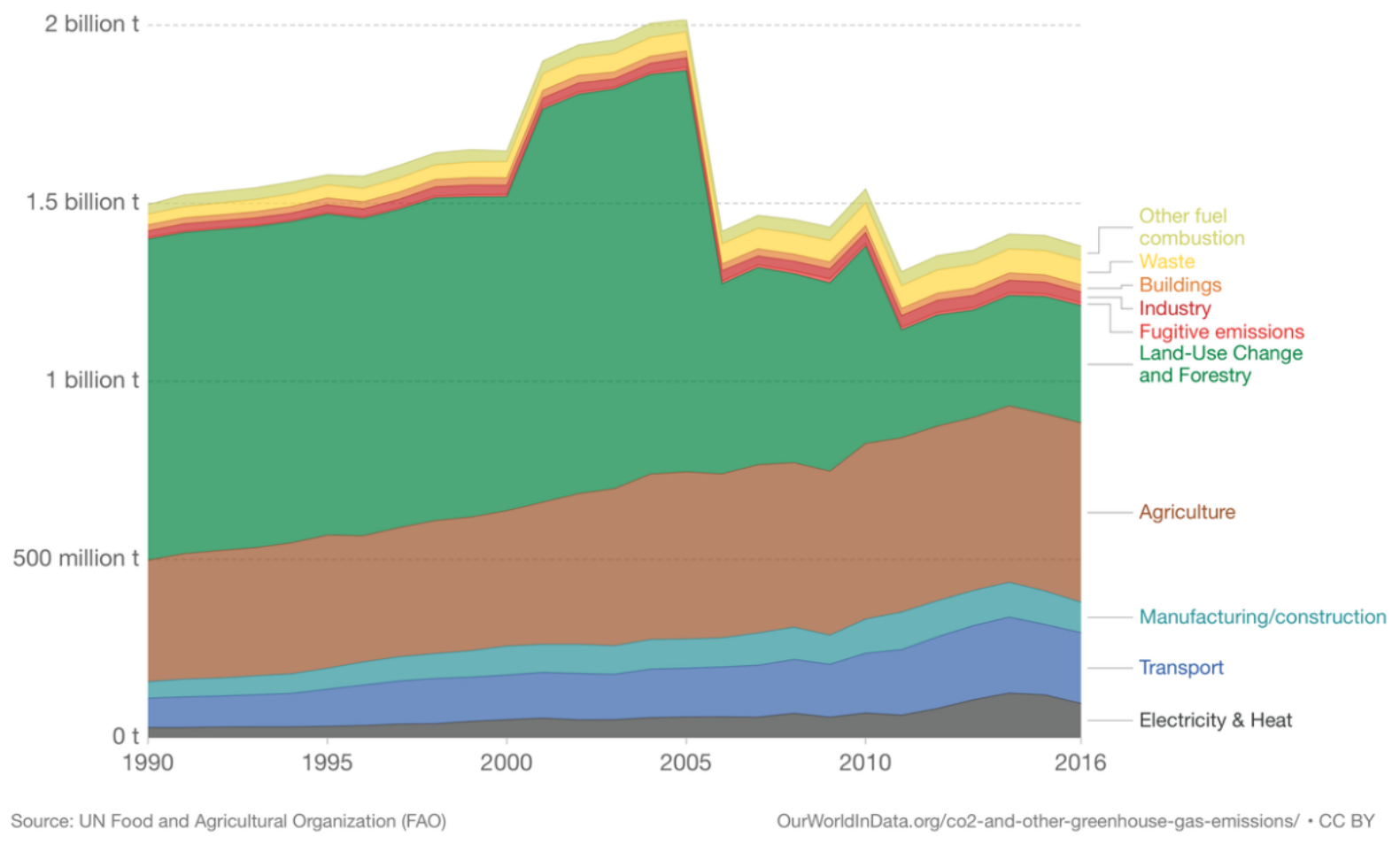

Figure 8: GHG Emissions by Sector in Brazil (1990-2016). Figure from: Our World in Data. 
Methane emissions by sector, Brazil

Methane $\left(\mathrm{CH}_{4}\right)$ emissions are measured in tonnes of carbon dioxide equivalents $\left(\mathrm{CO}_{2} \mathrm{e}\right)$ based on a 100-year global warming potential value.

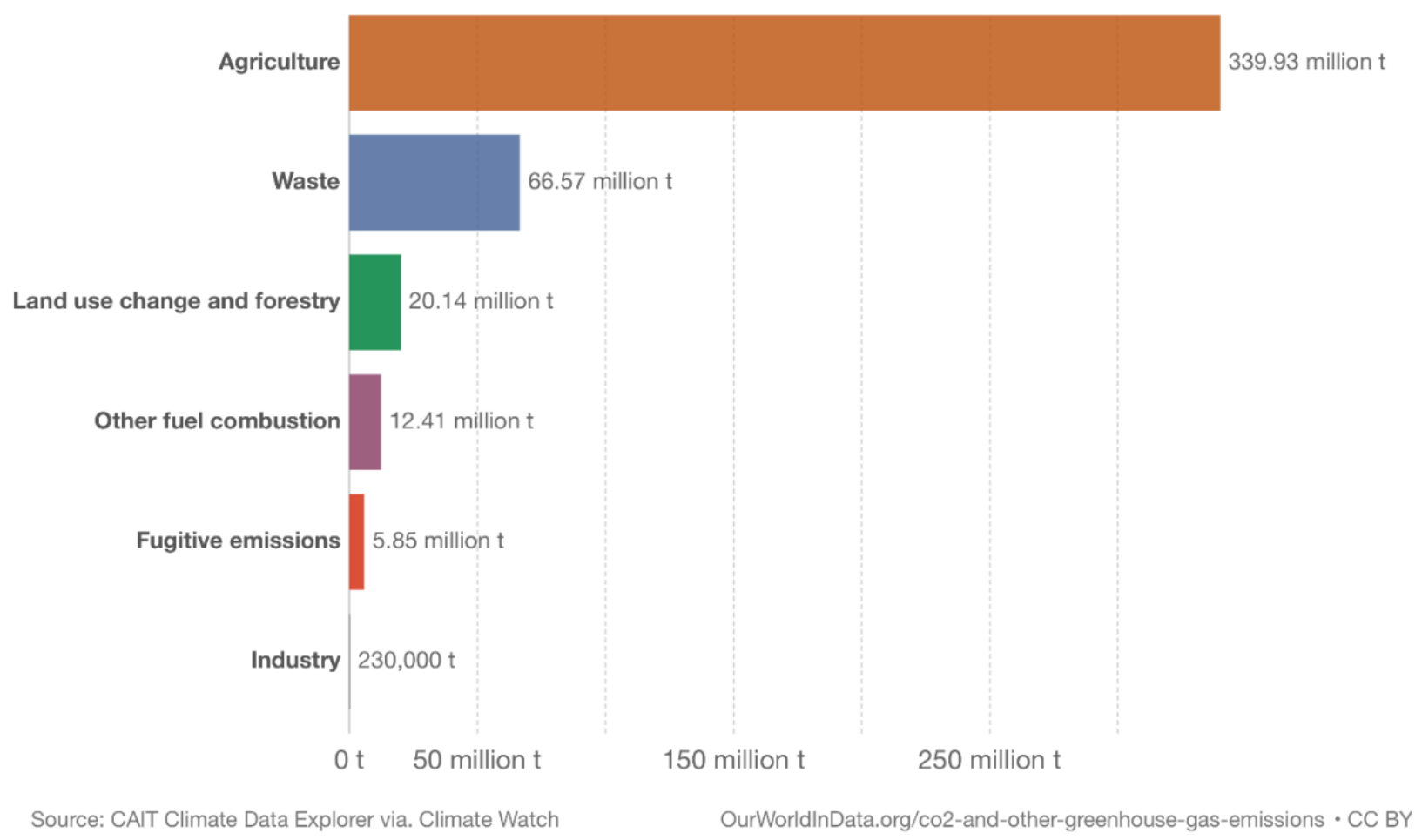

Figure 9: Methane Emissions by Sector in Brazil (2016). Figure from: Our World in Data. 
Nitrous oxide emissions by sector, Brazil

Nitrous oxide $\left(\mathrm{N}_{2} \mathrm{O}\right)$ emissions are measured in tonnes of carbon dioxide equivalents $\left(\mathrm{CO}_{2} \mathrm{e}\right)$ based on a 100-year global warming potential value.

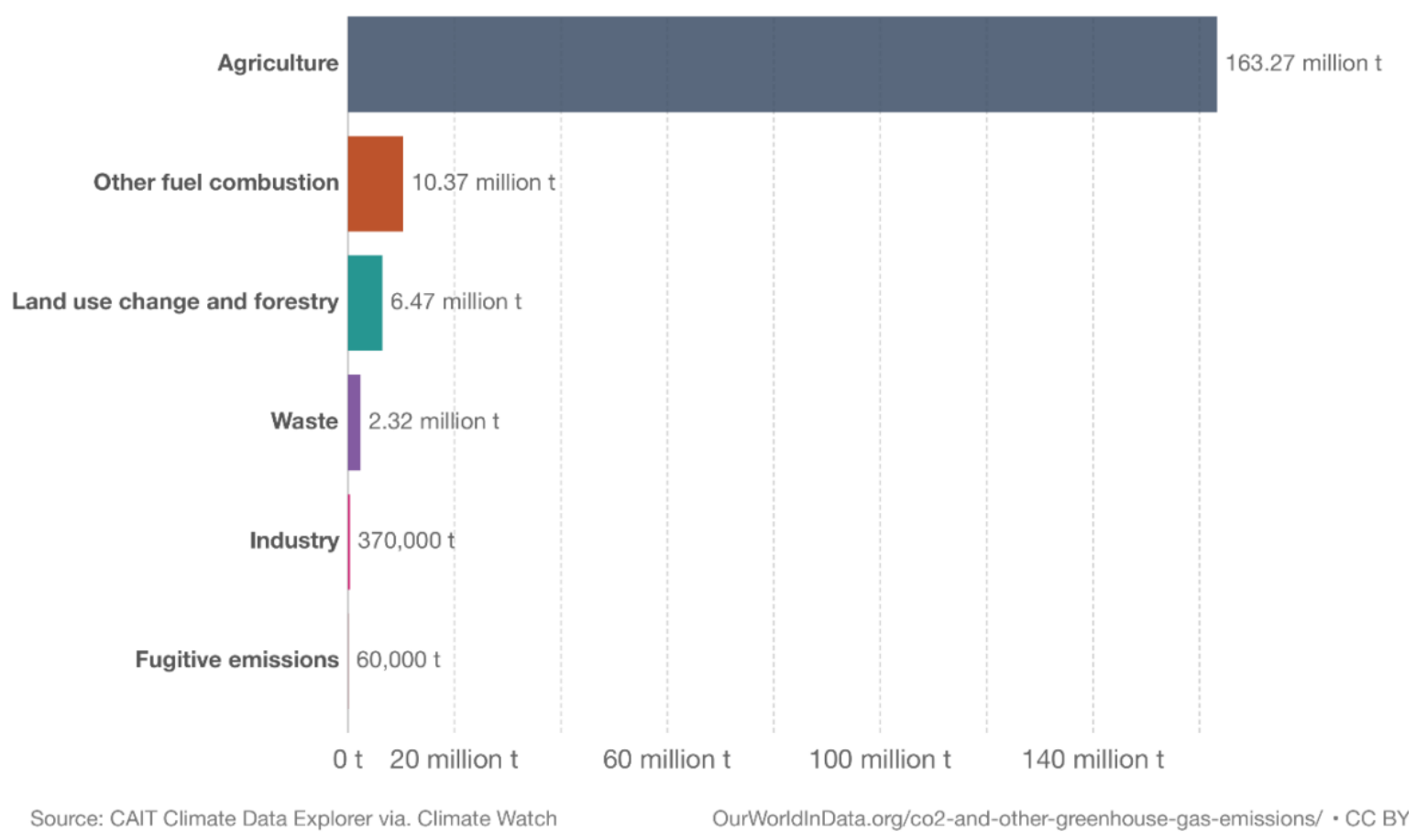

Figure 10: Nitrous Oxide Emissions by Sector in Brazil (2016). Figure from: Our World in Data.

\section{Physical climate change - risks, adaptation and opportunities}

\section{2.a Physical climate risk profile}

\section{2.a.i Physical climate risks that the country is already facing}

Brazil is the largest country in the Central and South American region, which has the "highest biodiversity on the planet and a variety of eco-climatic gradients". ${ }^{37}$. Nearly $60 \%$ of the Amazon Basin is located within Brazilian borders and $20 \%$ of the world's freshwater is located in the country. Brazil has suffered extensively from droughts, floods and wildfires throughout the 20th century. Climate has been a key driver of these events. But the occurrence and severity of such events is also highly dependent on land-use factors such as agricultural expansion and forestry removal practices. These risks pose varying degrees of threats to Brazil's distinct regions, especially when considering the rapid and pronounced effects of climate change. The country's Atlantic Forest is one of the world's three hotspots most vulnerable to climate change due to its susceptibility to invasive species and deforestation caused primarily from cattle grazing ${ }^{38}$. The savanna-type biome in the Center-West, an area known as the Cerrado, is also highly vulnerable due to the rapid and widespread land-use changes caused by agribusiness expansion and loss of original vegetation cover. ${ }^{39}$. The Amazon is experiencing 'savannisation' ('light' desertification) due to reoccurring droughts and rising temperatures ${ }^{40}$. There is also a clear link between deforestation and drought in the Amazon. The conversion of forest to cropland and pastures for cattle grazing reduces the level of evapotranspiration that generates regional rainfall 
patterns ${ }^{41}$. And the Caatinga semi-arid biome in the northeast of the country is experiencing risks from climate change in the form of rainfall variability, extreme droughts, land degradation and desertification ${ }^{42}$.

There are also current risks to the country's energy infrastructure due to climate change. Brazil use of renewable energy resources is four times higher than the global or OECD average, but it is heavily reliant on hydropower $\left(65.2 \%\right.$ of national total). ${ }^{43}$. Lower and uneven rainfall may affect the production of energy from hydroelectric sources, ${ }^{44}$, whether by drought or damages to the existing infrastructure by flooding ${ }^{45}$. Research thus far has shown that rainfall fluctuations will be highly regional as it relates to river basins used for hydroelectric power. For example, river discharge is likely to increase in the Northwest (+9\%) whereas it will likely decrease in the Amazon and Center-West $(-15.9 \%)^{46}$. Even more severe discharge decreases are expected in the most important river basins for hydroelectric power in the Northeast, including the São Francisco river $(-26.4 \%)^{47}$. Lowland coastal areas are currently facing vulnerability to flooding from inland due to higher and more concentrated rainfall as well as higher ocean levels and the increased occurrence of extreme coastal storms. ${ }^{48}$. Most of Brazilian territory experiences a rainy and a dry season (with a few exceptions ${ }^{49}$ ). These seasonal variations have already become more pronounced..$^{50}$. For example, since 1980, the Amazon Basin has experienced a $0.5^{\circ} \mathrm{C}$ increase in temperature during the dry season. ${ }^{51}$. Land-use change in the region also altered the methane-cycling in soils. The conversion of forest land to cattle pastures is driving changes in the microorganisms present in Amazonian soils. Researchers found that methane-consuming microorganisms are present in forested soils, but when deforested and converted into pastures, these microorganisms are replaced with methane-consuming ones, furthering the region from a methane sink to a source of methane ${ }^{52}$.

All of these human-induced changes have driven broader natural cycles that are furthering the loss of forests in the Amazon, which has increased the 'savannisation' of forests and the prevalence of forest fires. Some refer to this process as forest 'dieback' which is a climate-induced change where higher levels of $\mathrm{CO}_{2}$ in the atmosphere boost photosynthesis and promote vegetation growth. However, with limited water, the effect of higher $\mathrm{CO}_{2}$ in the atmosphere actually reduces the level of tree growth resulting in a transformation of forests to savannah-type vegetation. Additionally, forest loss is associated with a compounding loss in rainfall in throughout the country. ${ }^{53}$. The term "flying rivers" has been used to describe the process by which high-moisture regions, such as the Amazon, exhibit evapotranspiration that supports rainfall patterns in other regions of Brazil. ${ }^{54}$. Throughout the country, climate change is also causing further risks to biodiversity and the risk of invasive species establishment. Shifts in seasonal precipitation have caused risks to freshwater availability in some areas, flooding in others and coastal erosion along the coast. Deforestation in Brazil is aggravating broader global trends in temperature and precipitation change, becoming a net source of $\mathrm{CO}_{2}$ rather than a carbon sink as explained above. The loss of tropical forests in the Cerrado and Amazon biomes, in particular, is decreasing evapotranspiration which is accelerating regional temperature rises. ${ }^{55}$.

\section{2.a.ii How these risks are likely to change by $\mathbf{2 0 5 0}$ due to climate change}


Current projections under a business as usual situation for the Amazon, Northeast Brazil and Southeast South America are predicting a more than $2^{\circ} \mathrm{C}$ increase in temperatures ${ }^{56}$ for the Amazon region by 2050 , with some models showing a $2-3^{\circ} \mathrm{C}$ increase. ${ }^{57}$ Therefore, the aforementioned risks are likely to become more severe and potentially prolonged. Climate vulnerabilities in the Northeast are likely to worsen and will serve as a significant 'push' factor in out-migration. ${ }^{58}$ Furthermore, the existing climate and ecological relationships between regions are likely to worsen. For example, the Amazon Basin supports a large-scale movement of water vapor from the humidity of the Basin to the semi-arid region in the Northeast and supports the seasonal rainfall cycles in the Center-West and parts of the Southeast. Higher sea level rises could worsen coastal flooding and fragile ecological environments along the mouth of the Amazon, such as the newly discovered coral reef. ${ }^{59}$

\section{2.a.iii What additional long-term climate risks might be incurred before 2100 ?}

Climate change projections point to major increases in heat indices across Brazil for all scenarios ${ }^{60}$. Estimates show that the combination of deforestation and climate change could push heat stress exposure beyond human adaptation limits by $2100^{61}$. Without global action to reduce GHG emissions, regional temperatures in South America could increase by $4^{\circ} \mathrm{C}$ or more by the end of the century. There is some uncertainty yet on how these temperature increases will vary regionally, both in South America and Brazil, based on the IPCC WGI Interactive Atlas ${ }^{62}$. A group of Brazilian academics have warned that such an increase would have varied damaging effects ${ }^{63}$. For example, the Northeast region of Brazil is prone to periodic drought with regional projections indicating an increase in dryness by the mid to end of century ${ }^{64}$, and the region has a low level of climate change mitigation infrastructure. A regional temperature increase of $4^{\circ} \mathrm{C}$ could result in an unprecedented and prolonged extreme drought that would affect 1,000 different municipalities in the region and many more beyond ${ }^{65}$. Such a scenario would cause severe health issues due to heat and devastating losses in harvests, which would be catastrophic for local, regional and national food security ${ }^{66}$.

While extensive and extreme droughts are predicted for the Northeast, the majority of IPCC AR6 models project an increase in rainfall for the South and Southeast by 2100. The South and Southeast have a higher population density and increased gradients due to its mountainous and hilly terrain. Thus, higher rainfall would result in an increased susceptibility to flooding and landslides, the latter of which would be more pronounced in the regions' extensive urban areas ${ }^{67}$. Existing regional climatic scenarios of rainy and dry periods would be even further in doubt. Continuous rises in sea level would threaten the very existence of several large metropolitan areas and would drastically affect the over $60 \%$ of the county's population that lives in coastal areas $^{68}$.

2.a.iii How might different physical, sociological and economic risks and vulnerabilities interact? (correlated and cascading risks, multiple interacting risks, interconnectivity between these different physical climate risks)?

Although all the risks and vulnerabilities interact to an extent, there are several of note. Perhaps the most important for Brazil is the relationship between deforestation, GHG emissions and the physical impacts on economic sectors in the country. Agribusiness 
and livestock are the primary driver of land-use change and deforestation in the country. Agriculture represents $80 \%$ of all deforestation in the Amazon ${ }^{69}$ and the largest $2 \%$ of agribusinesses alone contribute towards $62 \%$ of illegal deforestation ${ }^{70}$. At the same time, deforestation poses a present and future risk to the viability of the agribusiness and livestock sector by accelerating climate change risks. Both land-use change and the agriculture and livestock sector account for approximately $60 \%$ of total GHG emissions in the country. Therefore, the relationship between deforestation and the agriculture and livestock sector is potentially cascading without immediate and drastic action. The upshot is that reforestation and a decoupling of agriculture and livestock from deforestation presents the opportunity to rapidly change the GHG emissions profile in Brazil. In particular, the Atlantic Forest ${ }^{7172}$ and the Amazon region offer the potential to serve as substantial carbon sinks for the globe and drastically reduce Brazil's total GHG emissions.

\section{2.b Sectoral and socioeconomic impacts of physical climate risks}

\section{2.b.i Economic sectors listed in section 1.a which are most exposed/vulnerable to physical climate risks}

Agriculture: This sector's reliance on seasonality and the environment makes it particularly vulnerable to climate risks. As mentioned, there are two generalized subsectors in the Brazilian agriculture and livestock sector: large-scale industrialized agribusiness and a smaller-sized family farm/peasant sector. The peasant sector refers to a class of rural producers who claim a legitimate right to work land for both commercial and subsistence production. Brazil has a rich history of peasant movements involved in a struggle over the right to land by occupying underutilized lands throughout the country ${ }^{73}$. Both of these subsectors are vulnerable to climate risks, albeit with differentiated risks and opportunities. The agriculture and livestock sector is both a contributor and exposed to climate change. Therefore, there is a cyclical relationship; mitigation, adaptation and resilience for agriculture and livestock need to be considered as a relational process.

Industry: The extractive industrial sector is the most vulnerable to physical climate risks. Activities in this sector include: mining, petroleum extraction and the processing of raw materials (biofuels, chemicals, cement making). Telecommunications and physical infrastructure, primarily roads and ports, also face vulnerabilities to climate change, especially in coastal areas and flood plains. Brazil's industrial sector is largely located in the Southeast and coastal region near the major urban areas of São Paulo/Santos and Rio de Janeiro. Santos is the country's largest port. A study determined that approximately $70 \%$ of Santos lies in "high vulnerability areas" to climate change-induced sea level rises, erosion and flooding ${ }^{74}$. A majority of the population in the Northeast region live in coastal cities, where urban coastal zones are also prone to erosion caused by sea level rise and increases in wave height ${ }^{75}$.

Services: Brazil's service sector is perhaps less vulnerable to climate risks in relation to the others. However, the service sector does generate and rely on the energy infrastructure, a majority of which is hydroelectric. The hydroelectric sector in Brazil is heavily reliant on non-reservoir dams. This makes the hydroelectric infrastructure in the country more vulnerable to fluctuations in rainfall. Under current models, drops in precipitation are projected to accrue economic losses to the tune of US $\$ 5$ billion a year 
until 2100 for hydroelectric companies under a business-as-usual approach to climate mitigation $^{76}$.

\section{2.b.ii Examples of how these sectors may be impacted by climate change including any material impacts on trade flows}

Agriculture: Much of Brazil's competitive advantage in large-scale industrialised agriculture is due to the ability of farms to employ double - and sometimes triple cropping. However, the ability to realize multiple harvests per year is intimately linked to the availability of water, through either rainfall or irrigation, and a reliance on chemical inputs. Climate change will likely affect both rainfed and irrigated multiple cropping systems. ${ }^{77}$ 95\% of crop losses in Brazil's agricultural sector occur due to problems of either drought or floods. ${ }^{78}$. Chemical inputs are also another dependency on fossil fuels, especially in the case of fertilizers. Multiple cropping systems are key to Brazil's agricultural productive capacity and therefore its agricultural exports. Climatic shifts may also present opportunities for expanding agricultural exports. For example, coffee and sugarcane production could potentially expand to higher latitudes. ${ }^{79}$.

Industry: Brazil has recently suffered two major mining disasters in the state of Minas Gerais due to the collapse of tailing dams. The collapses in the towns of Mariana and Brumadinho caused the loss of hundreds of lives and are considered the worst single damaging event to the environment in the history of Brazil ${ }^{80}$. Higher and more intense rainfall in the region could lead to more risky and expensive mining activities in the country. This is due to the shift in subsoil clay content that occurs from open pit mining in the region. ${ }^{8182}$ Mineral exports are responsible for approximately $2.5 \%$ of the country's GDP. ${ }^{83}$. Increasing costs due to changing environmental suitability under a changing climate would make Brazil's mining sector less competitive globally. ${ }^{84}$. Rising sea levels are also a significant threat to industry and the ability of Brazil to export. Brazil is home to many of the region's largest ports in terms of volume. The port of Santos in the state of São Paulo is the largest in Latin America and is currently facing issues of increased sedimentation, damage to port infrastructure due to more severe storms and flooding of equipment. ${ }^{85}$. Adapting Brazil's port infrastructure will be necessary to maintain the country's existing trade flows.

Services: Power generation and the energy matrix are the greatest services in Brazil at risk from climate change. A majority of Brazil's energy comes from hydroelectric sources. While these sources are renewable and relatively low emitters of GHG, they are vulnerable to changes in precipitation and rely on runoff. Prolonged droughts and the evaporation of reservoirs are the primary threats to Brazil's hydroelectric infrastructure, potentially resulting in up to a $20 \%$ drop in energy production. ${ }^{86}$. A particular region of risk is the Amazon, which holds $73.6 \%$ of the country's surface water. ${ }^{87}$. New forms of renewable and sustainable energy generation will need to supplement these losses in energy generation. A less desirable alternative would be to rely on regional partners to import energy.

\section{2.b.iii Demographic and ethnographic groups most at risk from climatic changes}


Rapid urbanization and industrialization characterized much of the $20^{\text {th }}$ century in Brazil. In just over 40 years, from 1950-2000, the country's rural-urban divide was inversed, from $70 \%$ rural in 1950 to $70 \%$ urban by $2000 .{ }^{88}$. As a result of the rapid urbanization process, rural poverty translated into urban poverty. The landless moved to informal, and often expansive, urban dwellings known as favelas. Favelas have been incorporating concepts of environmental sustainability and social inclusivity in their design/development but have long been viewed by the government as problematic, 'ungovernable spaces'. A closer look at their innovations for sustainability and social inclusion could benefit a net-zero pathway.

Both the rural and urban poor populations are at risk from climate change, and their risks are related. For example, changes in rainfall and higher temperatures may make droughts more common in some regions which will lead to a drop in productivity for farmers and even fires, pushing farmers out. ${ }^{89}$. However, other regions are projected to experience higher rainfall which could increase risks of flooding and landslides. ${ }^{90}$. Informal urban infrastructure in Brazil, such as favelas, are particularly prone to flooding, landslides ${ }^{91}$ and poor water quality. ${ }^{92}$. The result is that the rural poor may migrate to favelas in large urban areas, particularly in the Southeast region where they face different risks, yet just as severe.

According to the Brazilian Panel on Climate Change, a group of independent experts, residents in the Northeast region are the most vulnerable to climate change. ${ }^{93}$. It is this population that has the lowest income level and most vulnerable environmental and housing conditions, as well as a high reliance on agriculture and natural resources. ${ }^{94}$. The Northeast is also where the most severe effects of rising temperature and drought are predicted. ${ }^{95}$. The poorest inhabitants of the country will be most vulnerable to climate change. Poverty in Brazil is also correlated with race and ethnicity. For example, the poverty rate amongst Afro-Brazilians is twice that of those who identify as white. ${ }^{96}$. When looking at the bottom quintile of poverty in the country $49 \%$ are Indigenous and $33 \%$ are Afro-Brazilian. ${ }^{97}$. Therefore, not only do ethnic groups and Afro-Brazilians constitute a disproportionate share of the overall population living in poverty, but they also are more likely to live in extreme poverty. Climate changes will most affect the population living in poverty, with a disproportionate share of risk being placed on ethnic and racial minorities. This is true in a general sense across the country but also when looking at regions with higher indices of poverty ${ }^{98}$.

\section{2.b.iv Broader risks to sustainable development within the country/region that arise from physical climate change}

Food security: Despite being one of the world's largest agricultural exporters, almost $37 \%$ of Brazilians are considered food insecure..$^{99}$ Family farms are the primary source for domestic food security in the country, producing almost $90 \%$ of manioc, $70 \%$ of edible beans and a $1 / 3$ of rice consumed in the country. ${ }^{100}$. A majority of family farms are located in the Northeast region, identified as the most vulnerable to climate change. ${ }^{101}$ Family farms are also on the front lines of climate change mitigation, adaptation and resilience due to their silvicultural practices, which provide viable sustainable alternatives to agricultural production that relies on afforestation ${ }^{102}$. Silvicultural production systems refer to the "process of tending, harvesting and regenerating a forest" ${ }^{\prime 103}$. Climate change poses a risk to family farm production in the 
country. Such risks threaten to disrupt a key subsector that links poverty alleviation, human health, environmental sustainability and social inclusion.

\section{2.c Adaptation: Solutions \& Opportunities}

\section{2.c.i Country specific adaptation and resilience priorities against anticipated levels of climate change impacts}

Brazil's current Nationally Determined Contribution (NDC) to the Paris Agreement was adopted in 2020. The NDC uses 2005 as a baseline to reduce GHG emissions by 37\% in 2025 and by $43 \%$ in 2030. In order to achieve these targets, the government has adopted a series of sectoral plans for climate change mitigation and adaptation.

Agriculture/land use: The Brazilian government launched a "Sectorial Plan of Climate Change Mitigation and Adaption for a Low Carbon Emission Agriculture" (Plan $A B C)$ in 2010. The Plan has seven different programs: 1) recuperation of degraded pastures; 2) Agro-forestry systems; 3) No-till planting systems; 4) Biological nitrogen fixation; 5) Reforestation; 6) Animal waste treatment and; 7) Climate change adaptation. ${ }^{104}$. The overall goal of the plan is to "reconcile food security with environmental sustainability"105. Over the past decade, Plan ABC has financed about US\$3.4 billion for each of the programs with varying degrees of success in terms of lowering GHG emissions. However, the overall Plan has surpassed its goal of total planted area involved (both agricultural land and reforestation). Current estimates show that the Plan has the potential to lower agricultural GHG emissions by 133.9 to 162.9 million tons of $\mathrm{CO}_{2}$, or about $45 \%$, by $2025^{106}$.

The Plan still has numerous challenges. For one, it does not transform the agribusiness sector in the country. No-till planting systems ${ }^{107}$ and extensive livestock $^{108}$ grazing both rely on intensive fertilizers and chemical inputs, and reforestation goals will still fall short of meeting the necessary requirements to limit temperature rise to below $2^{\circ} \mathrm{C} .{ }^{109}$ Additionally, the distribution of the Plan's funds throughout the country has heavily favoured richer farmers in the more well-off regions of the Center-West and Southeast. ${ }^{110}$ Therefore, although the plan presents technical solutions to climate change, the social and geographical distribution in funds means that it likely has limits in its effectiveness.

For land use, the government committed in 2009 to reducing deforestation $80 \%$ by 2020 (using the average of 1996-2005 as the baseline). Despite early gains until 2013, deforestation rates started to climb and there was a $34 \%$ and $47 \%$ increase in deforestation in 2019 and 2020, respectively. When considering these most recent figures, deforestation is actually $182 \%$ higher than the government's target set in 2009 (see figure 6). ${ }^{111}$ Deforestation is overwhelmingly driven by the agribusiness sector with only $2 \%$ of all farms in the Cerrado and Amazon being responsible for over $60 \%$ of all illegal deforestation. Close to half of all agribusiness farms are not in compliance with the Forest Code (discussed below). ${ }^{112}$

Industry: In the mining sector, the Brazilian government launched the "Sectoral Plan of Climate Change Mitigation and Adaptation for Mining" in 2009. The Plan has the following objectives: 1) contribute to reaching the national voluntary guidelines of 
reducing GHG emissions under the NDC; 2) Strengthen knowledge with respect to GHG emissions involved with mining and mining companies; 3) Promote efforts to transform good practices of GHG emissions reductions under a national framework; 4) Influence and stimulate the development of policies that assist small mining companies to adopt actions for GHG emission mitigation; 5) Integrate the mining sector within national public policies aimed at climate change mitigation and adaptation; 6) Develop mechanisms that incentivize a greater investment into research and development for small and medium companies in the sector. ${ }^{113} \mathrm{~A}$ specific plan for the steel industry was launched in 2010 that aims to replace native forest charcoal used in the smelters with planted forest charcoal. ${ }^{114}$ Emissions from the mining sector have dropped since a peak in 2012 but only by about $15 \%$ until the most recent data in 2016. ${ }^{115}$

The country is also in the process of developing a plan to curb deforestation, particularly in the Amazon. It is called Amazon Plan 21/22 and primarily focuses on combatting illegal logging and forest fires in the region. Thus far, the plan aims to integrate institutions responsible for monitoring and enforcing illegal logging and the presence of forest fires, while also promoting civil society actions to support sustainable development actions. ${ }^{116}$ The goal is to revert forest loss to average levels observed from 2016-2020 (around 8,700 km2). The plan falls short by not considering the role of existing infrastructure in furthering deforestation and fires in the region, such as the construction of highway BR-319 in the Western Amazon. ${ }^{117}$ One of the more promising actions of the government to combat deforestation is the adoption of payments for ecosystems services at the national policy level in January, 2021 (Law No. 14.119, January 13th, 2021).

Services: One of Brazil's achievements over the past 15 years has been the expansion of biofuels to replace oil-based fuels for automobiles and road transport. Biofuel use grew by about $8 \%$ a year until reaching about $50 \%$ of replacing traditional oil-based fuels such as diesel and gasoline. That figure stands in contrast to the rest of the world where only about $3 \%$ of biofuels replace oil consumption. ${ }^{118}$ However, biofuel production and consumption is now in decline. ${ }^{119}$. There are also doubts about the overall sustainability and inclusivity of biofuels as they tend to rely on large-scale industrial monocropping. ${ }^{120}$. In 2003, the government launched a program called "Energy for All" (Luz para Todos) that subsidized the costs to expand access of rural families to the energy grid. The program was largely successful and today Brazil's energy grid reaches $99 \%$ of the population.

In the energy sector, Brazil's Ministry of Mines and Energy launched a plan in 2018 to contribute towards the country's NDC. The plan has several goals to achieve by 2025 : 1) to increase the total share of bioenergy to $18 \%$ of the total energy matrix; 2) to reach $23 \%$ of total generation coming from wind, solar and biomass electricity generation and $66 \%$ of hydroelectric; 3 ) to gain $10 \%$ in terms of electric efficiency; 4 ) to reach $45 \%$ of all energy in the national matrix to be renewable. ${ }^{121}$

As a part of the original commitments to reduce GHG emissions in 2009, the Brazilian government established a Climate fund to finance the National Climate Policy Plan/NDC. However, the fund is currently at the center of an intense political debate and legal case. In June of 2020 four political parties launched a legal case against the current presidential administration that claims only US\$141,000 of the fund's US\$1.6 
million was allocated in $2019^{122}$. Therefore, while the legal case will be played out, uncertainties have been raised around the current presidential administration's commitment to ensure the implementation of the country's climate change policies in a consistent and legally binding manner.

\section{2.c.ii Current/future solutions which have the potential to satisfy adaptation needs, including transformation}

Many of the environmental policies developed by previous administrations in the previous decade have been discontinued under the current administration ${ }^{123}$. The arena that has suffered with regards to climate change, in rhetoric and practice, has been deforestation in the Amazon ${ }^{124}$. Notwithstanding the revised NDC, Brazil continues to uphold the voluntary commitments GHG emission reductions agreed upon at the Paris Agreement. Yet, there are several current and future solutions that can improve climate adaptation in the country.

Agriculture and livestock: there is a need to rapidly decrease the reliance on external inputs for agricultural production and livestock grazing. In the former, Brazil is the world's largest consumer of both fertilizers and pesticides. Not only does this appetite for inputs serve large-scale monocropping that is vulnerable to climate change, but it is also damaging the health of producers and consumers ${ }^{125}$. Livestock grazing in Brazil is the most extensive grazing operation in the world, covering $20 \%$ of all Brazilian territory ${ }^{126}$. Around $70 \%$ of all cattle grazing is on an imported tropical grass known as Brachiaria, which relies on fertilizers to correct the acidic soils of the Amazon and Cerrado. This has resulted in estimates of up to $80 \%$ of all cattle grazing soils being considered degraded and increased methane emissions from both the cattle and changes in soil microorganisms ${ }^{127128}$. Solutions include: mixed-cropping systems (i.e. agroforestry, silviculture and other permaculture practices ${ }^{129}$ ); improved soil management; land reclamation; reforestation of tropical forests (particularly in the Cerrado and Amazon ${ }^{130}$ ); import tariffs on agricultural inputs; subsidised credit for family farms ${ }^{131}$; the enforcement of the Forest Code and; land reform. The Landless Workers' Movement (MST) is the world's largest rural social movement in the world and has been a leading political figure in the fight for land reform in Brazil. Government legal and financial support for the MST's activities of settling families in underutilized areas would be one way to facilitate a socially-inclusive land reform policy. The current presidential administration has taken a strong stance against both agrarian reform and the activities of the MST. Nevertheless, the MST has demonstrated the administration's lack of social protection measures for vulnerable rural populations and has served as a key network of solidarity and social support during the Covid-19 pandemic ${ }^{132}$.

Land use and natural resources: One of the widely recognized achievements of Brazilian legislation in combating land use change and deforestation is the Forest Code. According to the law, farmers must maintain a percentage (35-80\%) of their land untouched to remain under its native vegetation. In the Amazon, this percentage is as high as $80 \%$. However, the Brazilian government has historically not enforced this quota by prosecuting non-compliance. Part of the reason for this is due to problems in the land registry to locate landowners ${ }^{133}$ but the logic of saving a portion of land while degrading the rest has also shown to not be effective in conserving biodiversity ${ }^{134}$. A more holistic approach is needed that supports productive activities 
with environmental conservation. Examples of more sustainable forms of extractivism are present throughout Brazil, but lack political support and are limited due to the economic subjugation of the environment ${ }^{135}$. Ideas of and support for sustainable extractivism include: minimum income for producers to engage with more sustainable methods of agriculture and extraction; ecosystem services; agroforestry; subsidised local food systems (including school meals, linking family farm production with local and regional food insecurity ${ }^{136}$ ); the participation of civil society and local stakeholders in extractive activities, such as mining ${ }^{137}$.

Physical infrastructure: The existing port infrastructure will need to be updated to account for rising sea levels and the prevalence of increasingly severe coastal storms (and the associated storm surges, potential flooding and runoff/sedimentation) ${ }^{138}$. Adaptation measures include: reinforcing storm walls, docking facilities and the construction of levees and dams for coastal urban areas. The government should conduct further scoping studies on the possibility of building a passenger rail network throughout the country and expand the existing, but limited, transport rail network. Electric rail could draw on the hydroelectric capacity of the country to provide a truly low carbon transport infrastructure. The Brazilian government recently launched a green bond program with close to US $\$ 3$ billion in investments to expand the rail freight network, mostly directed for the transportation of agricultural goods ${ }^{139}$. In addition, Further studies need to be conducted on the improvement of the existing road network, but also with complementary research on the link between the expansion of roads with increasing deforestation and other extractive activities. Road washouts are a common occurrence in much of the country but could get worse with more intense rainfall in shorter periods of time ${ }^{140}$. Adaptation measures include: enhanced road monitoring and forecasts, investments in bridges and raised roads and the construction of natural erosion barriers.

Energy generation: Brazil's hydroelectric infrastructure is a relatively low-carbon source of energy. However, it relies mostly on dams that harbour low to no reservoirs. Regional changes in rainfall means that the country needs to construct dams that build reservoir capacity during times of high rainfall to maintain energy generation during prolonged dry periods. Brazil has diversified its renewable energy matrix with the development of wind power in the Northeast. Studies demonstrate that the region could sustain further expansion of wind turbines in the region, which has high wind capacity year round ${ }^{141}$. Another future solution to expand low-carbon electric generation in the country is to build a solar network in the Northeast. This region's semi-arid climate presents opportunities for extensive and intensive solar plants that could even be built and maintained with local labour, which would provide high-paid employment opportunities to the poorest region of the country ${ }^{142}$. Household solar units could also be a solution and, if they are manufactured in Brazil, could offer employment opportunities and domestic innovation.

\section{2.c.iv Locally specific emerging sectors that might be of future importance for adaptation and mitigation}

Circular and social bioeconomy: Current and future solutions exist to more sustainably exploit the rich biodiversity found throughout Brazil's five major biomes. In particular, developing a bioeconomy in the Amazon could be more socially inclusive and environmentally sustainable than current trends of agribusiness expansion and 
deforestation. The bioeconomy refers to the application of biotechnologies to understand and create value out of the region's rich biodiversity, which include: food and drinks, cosmetics, traditional and natural medicines, other pharmaceuticals and knowledge ${ }^{143}$. The bioeconomy presents a solution to develop bio-based products, instead of fossil-fuel based ones, across these sectors with the potential to also fuel innovation in the country ${ }^{144145}$. Traditional and indigenous populations are part of the solution. Under the bioeconomy, knowledge and technologies extracted from the region are based on the principle that Indigenous populations hold the intellectual property to nature in the region. Any products or knowledge generated will then provide them with the opportunities to benefit economically from royalties as well as employment opportunities in the construction of an emerging biotech sector ${ }^{146}$. Reforestation and environmental conservation is central to the creation of a bioeconomy because biodiversity and native vegetation is at the heart of its functioning.

The state of Paraná in the Southeast region is building the country's first wastegenerated power station that will use 1,000 cubic meters of sewage sludge and 300 tons of organic waste per day. The plant will also convert organic waste into biofertilizers and hopefully produce biodegradable plastic bags. The power generated from the plant will produce enough energy to supply 2,000 households in public housing projects ${ }^{147}$. Although Brazil is still behind many other countries in waste-topower circular economies, this plant in Paraná could offer a desirable path for other areas in the country. Over $10 \%$ of waste in Brazil is disposed in open air dumps. There is a high potential capacity for circular options of waste-to-energy in the country. A proposal to build another energy plant in the Southern state of Santa Catarina is underway and other state and municipal governments in Brazil may soon explore the option too ${ }^{148}$. Financial support from the federal government could give a boost to the currently dispersed proposals.

Nature-based solutions (NBS): These current and future solutions rely on the protection, management and restoration ${ }^{149}$ of biodiversity in Brazil, including the Cerrado savannas, forests in the Amazon and Southeast, and the semi-arid regions in the Northeast. Brazil has the largest carbon sink in the world with the tropical forests of the Amazon. Therefore, immediate steps to protect, manage and restore its forests can play a crucial role in reducing $\mathrm{CO}_{2}$ emissions globally. NBS includes: ecological engineering; ecosystem-based adaptation; ecosystem-based disaster risk reduction; green/blue infrastructure; integrated land management; agroforestry; agroecology; forest and landscape restoration; reduced emissions from deforestation and degradation (REDD+)/ecosystem services; natural climate solutions; nature's contributions to people; nature's contribution to adaptation and; managed realignment ${ }^{150}$. One example of NBS in Brazil can be found on the Madeira River, the Amazon's largest tributary by discharge. The Madeira River is one of the world's last remaining major rivers without any managed navigation channels (i.e. dams, locks, canals or dredging). On the Madeira River, an international collaboration is underway to support sustainable management of the river in consultation with local populations that will maintain the natural flow of the river without building navigation channels. The approach uses a Working with Nature philosophy of identifying safe passageways on the river without altering its flow ${ }^{151}$. 
Social and Solidarity Economy: What Social and Solidarity Economies (SSE) do is promote "spaces of autonomy" for communities to establish alternative economies to the neoliberal model, which has historically excluded a large share of the Brazilian population. SSE is based around organizing economic activities for social profitability instead of financial profits. Brazil has a rich history of establishing a range of SSE in different municipalities in order to promote community development and poverty reduction ${ }^{152}$. There are several components that can help support SSE as a solution for more sustainable development and climate adaptation and mitigation in Brazil. Incubators, public funding for enterprises and public education can help generate human and financial capacity to support the growth of SSE throughout the country ${ }^{153}$. SSE principles also embrace circular economies to reduce and reuse otherwise discarded materials by basing them as their social, rather than economic, value ${ }^{154}$. Through community-led initiatives, SSE is envisioned as a desirable social platform to achieve the Sustainable Development Goals (SDGs) ${ }^{155}$. In Brazil, SSE have established important linkages with sustainable agricultural production and food markets in the country, as well as the expansion of agroforestry networks in the Amazon region ${ }^{156}$.

\section{Development compatible transition - risks, mitigation and opportunities}

\section{3.a. Socioeconomic and sustainable development risks of a net zero transition}

\section{3.a.i How different demographic and ethnographic groups would be impacted by a net zero transition}

Deforestation, land-use and large-scale industrial agriculture contribute to an over half of GHG emissions in Brazil at 55\%. Therefore, at a general level, more wealthy rural populations would be most negatively impacted whereas a majority of the urban population would benefit. As agribusinesses are the primary drivers of deforestation and land use change, they can contribute to the most drastic reductions in emissions. Measures to stop deforestation and limit the use of inputs would mean a loss in revenues for agribusiness in the short term.

A net zero transition could increase rural-urban migration if agriculture (and agricultural wages) sees an increase in production costs. This is especially the case if small and medium-sized producers are excluded from compensatory schemes, such as payments for ecosystems services ${ }^{157}$. A further increase in translating rural poverty to urban poverty could put pressure on both existing and the potentially incoming favela residents, especially in the largest cities of the country ${ }^{158}$. Small and resourcepoor rural dwellers face systematic barriers to gain legal access to land and to the resources upon which they make their livelihoods ${ }^{159}$. Any net zero transition should consider these systematic legal barriers in order to be more inclusive. Additionally, studies have shown that the concentration of land speeds up deforestation rates, particularly in the Amazonian region ${ }^{160}$. The most unequal states and those with a high incidence of poverty will be most immediately impacted by a net-zero transition. This includes populations that live in the Northeast, North and Center-West regions ${ }^{161162}$.

Depending on the nature of the transition, Indigenous groups could potentially not receive adequate monetary or in-kind compensation for their knowledge and services in the bioeconomy and different forms of nature-based solutions. Indigenous reserves 
in Brazil have historical precedent, even if they are limited in their territorial and anthropological reach. The expansion of existing reserves and the creation of new ones would have the dual effect of forest conservation and cultural preservation. If coupled with a payments for ecosystem services scheme, then Indigenous reserves could also serve as a social protection program as well. In the early 2000 s, raises in the minimum wage and social policies propelled a rise in what some scholars have termed a "new middle class" in the country ${ }^{163}$. However, many of the successful social welfare policies were dismantled starting in 2016 under the current government. Market disruptions are likely in the energy and food sectors. This could likely lead to higher prices for cooking gas, electricity, basic food baskets and fuel for transportation, which have already been increasing substantially over the past five years due to inflation ${ }^{164}$.

\section{3.a.ii Risks to broader sustainable development within the country/region that could arise}

If the co-benefits of transition financing are not clearly articulated this could be framed by the Brazilian government as a rationale for scaling-back budget allocations in other crucial areas such as healthcare, education and other public welfare programs ${ }^{165}$. A rollback of social services could threaten the political viability of a net-zero transition. The government will need to carefully manage the transition to ensure that the inclusion of vulnerable populations is accompanied by education and training to be suitable for the new employment opportunities in a net zero economy.

There are also trade-offs in the development of new infrastructure and technologies. Low carbon technologies, such as hydroelectric power and transport rail networks could help reduce emissions in the short-term; however, they may also result in furthering deforestation, the loss of livelihoods and natural resource extraction. On the one hand, passenger rail, in particular, would be more beneficial all around, as resource extraction is indirectly linked to the movement of people. On the other hand, efficient passenger rail would also lower emissions by replacing car transport. One study found that even just the use of freight rail would reduce GHG emissions by up to $77.4 \%$, be up to $43.5 \%$ more fuel-efficient and up to $80 \%$ cheaper than relying solely on roads ${ }^{166}$. The expansion of infrastructure could have trade-offs with existing vulnerable groups that are more isolated. For example, Indigenous populations would benefit by the new connections and economic opportunities of integration, but agribusinesses and other extractive activities may also arrive with newer, more efficient transport networks. The active participation and prior and informed consent of vulnerable populations could help minimize the impacts and maximize the cobenefits.

\section{3.b Just Transition}

\section{3.b.i What are the priorities for enabling a just transition in this country?}

Brazil is home to an extremely diverse population and characterised by extreme levels of inequality and poverty. Therefore, poverty reduction and combatting inequality is a priority. Solutions such as the bioeconomy and NBS need to involve relevant stakeholders in an inclusive manner - including Indigenous, traditional peoples and Afro-Brazilians. Any broad-based net-zero future for Brazil will necessarily involve the 
meaningful participation of these historically marginalised populations. Cash transfers and other poverty alleviation programmes enacted over the previous two decades had important spill-over effects on reducing climate-based stresses ${ }^{167}$. Increased incomes allow those living below the poverty line to diversify their economic activities and become less reliant on natural resource extraction. Another priority is to reform the tax system. Brazil has a highly regressive tax system based largely on consumption. Changes to tax the energy sector, land/real estate, finance and GHG emitting industries, perhaps through inheritance and carbon taxes, could enable a more just transition ${ }^{168}$.

In addition to income inequality, Brazil is one of the most unequal countries in terms of access and ownership of productive resources (i.e. land, water, credit). These inequalities are especially pronounced in rural areas and the regions of the North and Northeast. Policies such as land reform and subsidized credit for small and medium rural producers would have the dual effect of supporting poverty reduction and food security.

Brazil's public research infrastructure is a priority for enabling growth in the bioeconomy and the productivity of small rural and urban entrepreneurs. In the case of the bioeconomy, public research can help ensure transparency in the participation of Indigenous and traditional communities, while also maintaining knowledge and technologies generated remain public goods for Brazilian society. Public investments in science and technology can also further innovation in the circular and bioeconomy, such as sustainable agriculture, natural synthetics, cosmetics and pharmaceuticals ${ }^{169}$.

\section{3.b.ii What are some examples of future opportunities that could enable a just transition in this country, including adaptation to transition risks?}

The government could expand and create new participatory institutions at several levels. For example, the Brazilian city of Porto Alegre has been a model case in developing participatory budgeting at the municipal level ${ }^{170}$. In the arena of food security, the federal government established a participatory forum where civil society leaders were able to interface with ministries on the development of policies for food and agriculture ${ }^{171}$. Such institutions would facilitate a more participatory process of enacting the transition, as well as ensure more broad-based public support in the longterm.

Migration of people across regions could also provide future opportunities in terms of fulfilling employment needs in both rural and urban spaces. For example, more labourintensive agriculture has been shown to be more productive for food (per calorie), more sustainable, supportive of higher incomes and attentive to the local dietary preferences of the population ${ }^{172173}$. Reforestation combined with settlement can also provide future opportunities for agricultural growth in areas that are currently already experiencing risks from climate change, such as the Amazon. Peasants and smallholders in the Amazon have the capacity to generate productive systems that are more sustainable, productive and contribute towards the food security needs of the Brazilian population ${ }^{174}$. The term peasants in Brazil has long been connected to a political claim to land for those who work it ${ }^{175}$. Existing peasant movements, such as the aforementioned MST, provide a social platform to engage peasants and the rural poor in other economic inclusion activities. For another example, a new energy 
infrastructure, especially solar, could also provide employment opportunities in the semi-arid Northeast region under cooperation with social movements..

In urban areas, informal communities (favelas) are already providing solutions for more sustainable development by building solidarity networks, organic architecture and the promotion of public use spaces. However, a transition will provide future opportunities for income generation. Initiatives such as ecosystems services and nature-based solutions can provide a more just transition that has long-term benefits for infrastructure development and climate adaptation ${ }^{176}$. Public financing of green buildings for vulnerable population could reduce GHG emissions and attend to the housing needs of some 20 million people currently living under informal conditions. Additionally, by compensating poor urban communities for the ecosystem services employed within them, more vegetation will help mitigate the risk of floods, landslides and help lower local temperatures.

\section{3.c Sectoral and socioeconomic impacts of a development compatible transition under each of the following transition pathways}

\section{- Steady, orderly, persistent transition pathway}

Brazil has been leading the developing world in terms of voluntary commitments to reduce GHG emissions. However, the current commitment to the Paris Convention is to reduce GHG emissions by $43 \%$ in 2030 , using 2005 as a baseline. Therefore, a net zero pathway could potentially be another $70-80$ years if following the same timeline as the Paris Convention commitment. Nevertheless, Brazil has a substantial capacity to serve as a carbon sink and the deployment technologies such as carbon capture and storage associate with biomass could rapidly change the current outlook ${ }^{177}$. The combination of an accelerated reduction in GHG emissions and sectoral commitment on behalf of public financing and the private sector would make a transition pathway possible. However, the agricultural sector will likely suffer the most severe of the impacts. Agribusiness and livestock account for a majority of deforestation and GHG emissions within the sector ${ }^{178}$. For example, soybeans, corn and sugar cane accounted for $84.4 \%$ of total cropland area in $2017^{179}$. Under a net zero transition, soybean area alone would reduce by almost $40 \%$ by 2050 with a $34 \%$ decreased share in export volume. For corn, the cultivated area would reduce by $37.5 \%$ and a drop in export share by $31.9 \%$ with the same 2050 goal. Sugar cane, however, is predicted to grow in cultivated area by $5.4 \%$ due to the use of biofuels ${ }^{180}$. Thus, there will be significant challenges for large-scale producers with a few opportunities to transition towards other crops.

The energy sector, however, is projected to meet and perhaps even exceed the required reductions in GHG emissions to meet the 2030 commitment $^{181}$. Additionally, Brazil is in a favourable position to achieve net zero emissions ahead of the global average due to the capacity of forest and reforested areas to serve as a carbon sink ${ }^{182}$. Brazil's independent panel on climate change has submitted a zero carbon plan by $2060^{183}$. However, that plan has not yet been adopted by the current government. Then, at the end of 2020, the federal government announced that such a goal would be possible if other countries would contribute US $\$ 10$ billion a year, specifically aimed at land use change and curbing deforestation ${ }^{184}$. Therefore, a steady, orderly and persistent transition pathway will be reliant on reductions in GHG emissions from the 
agriculture and livestock sector as well as land use. As discussed above, these two sectors are intimately related.

\section{- Late, disorderly transition pathway}

A late and/or disorderly transition is a significant risk to Brazil's most important economic sectors. Studies have shown that agricultural growth and the value of agricultural exports have actually increased while deforestation decreased ${ }^{185}$. Further, as previously discussed, increased GHG emissions from deforestation will increase risks of climate change on the agricultural and livestock sector. Such a transition would limit land availability for production and drive further the degradation of lands on the Amazon-Cerrado frontier. Some researchers refer to deforestation in the Amazon as having a "tipping point" where a $20-25 \%$ loss in vegetation would result in the region transforming into a savannah ecosystem ${ }^{186}$. Any efforts to reset the rainforest ecosystem would be lengthy and extremely costly, both to reforest and due to the environmental damages caused to other regions and economic sectors.

In other words, land use and agriculture are intimately connected in any pathway. A disorderly pathway to reductions in GHG emissions in either of them would disrupt the other and result in economic losses and regress previously achieved reduction goals. A failure to avoid the "tipping point" would further the economic losses and costs to maintain the Amazon as a functioning ecosystem and its ability to serve as a carbon sink.

\section{3.c Sectoral Impacts}

\section{3.c.i Sectors mostly likely to be impacted by a net zero transition, including any material impacts on trade flows, and considering both risks and opportunities}

Agriculture and livestock: As mentioned, there are generally two broad subsectors within agriculture and livestock: large-scale agribusiness and small to medium family farms. The former comprises productive systems primarily for export and are also the largest producers of GHG emissions within the sector ${ }^{187}$. Agribusiness, primarily in the livestock sector, is also the primary driver of deforestation. Therefore, the greatest risks of a net zero transition are for agribusiness and livestock. The costs associated with a net zero transition could have a significant impact on trade flows as the agribusiness subsector comprises $40 \%$ of total exports for the country ${ }^{188}$. These risks could come in the form of broad-based reforestation, which would have the dual effect of removing emissions and adding to the capacity of the country's carbon sink. Additionally, land redistribution would support employment generation and the expansion of smaller-scale, and potentially more sustainable, farming systems. The family farm sector in Brazil produces primarily for the domestic food market. There are much fewer risks on the family farm sector for a net zero transition and very little impact on trade flows. On the contrary, the family farm sector could capitalise on a net zero transition by increasing productivity of agroforestry and other diversified farming systems.

Land use and natural resources: Land use is closely tied to the agriculture and livestock sector. However, it also involves the logging industry, firewood for cooking, biomass extraction and other minor economic activities. A net zero transition signifies 
impacts on the land use sector by reclaiming, protecting and restoring forests and other native vegetation. Brazil's exports from land use are relatively minor; however, the connections to the agriculture and livestock sector mean that conservation of land will impact the trade flows of that other sector. There are risks that the conservation strategies could exclude Indigenous and other traditional communities who rely on the environment for their livelihoods and identity. Yet, there are also opportunities to involve them with initiatives such as the bioeconomy and nature-based solutions. An inclusive net zero transition would involve the participation of Indigenous and traditional communities from design, implementation and evaluation. There are also opportunities to implement a registry for products that can be considered "deforestation free" for domestic and foreign markets. This would help incentivize agribusinesses to capture market opportunities and it would help inform consumers of how their consumption is connected to land use in Brazil ${ }^{189}$.

Brazil is the world's second largest producer of iron ore and a global leader in other minerals. A net zero transition will not have a substantial effect on mineral exports for the country. However, more sustainable and socially inclusive mining could present some opportunities. For the former, more efficient water use and lower-impact land use change, based on land restoration, can result in better practices for extraction of minerals that consider long-term investments on the land and its local inhabitants ${ }^{190}$. The participation of local stakeholders, especially Indigenous and traditional peoples, can provide opportunities for employment, a stake in the productive extraction and linkages between mining operations and local knowledges.

Physical infrastructure: Brazil's physical infrastructure continues to vary drastically by region, both in terms of type and condition. For example, water is the primary mode of transport in the North region whereas roads dominate elsewhere. In the Northeast, the road transport infrastructure is severely dilapidated in areas, and especially in more sparsely populated rural areas. The country's largest ports were historically built by public funds and, until recently, were managed by public companies. Almost $95 \%$ of Brazilian cargo is transported through the some 215 ports in the country, with the port in Santos, São Paulo managing $40 \%$ alone ${ }^{191}$. A net zero transition presents opportunities to modernise the port infrastructure, which is considered vulnerable to climate change. However, the potential negative effect of a net zero transition on the agriculture and livestock sector could result in less cargo and, ultimately, lower revenues for the maritime transport industry.

The domestic transportation matrix in Brazil relies primarily on roads $(61 \%)$ and only $20 \%$ of transportation occurs via rail ${ }^{192}$. A net zero transition offers opportunities to minimise GHG emissions by investing in the country's rail infrastructure. This could include urban commuter rail, cargo rail and intercity rail, the latter of which is completely non-existent at present. A more extensive rail network could present opportunities for lower cost transportation of goods, a comparative export advantage in other key sectors and economic integration of major urban centres. The 'industrial triangle' of São Paulo, Rio de Janeiro and Belo Horizonte contain a combined population of around 40-50 million people and are less than $500 \mathrm{~km}$ between each other. However, a current reliance on roads means that travel between them can take anywhere from 5-8 hours. Investments in Brazil's physical infrastructure presents numerous economic opportunities under a net zero transition. 


\section{3.d Development compatible emissions: Solutions \& Opportunities}

\section{3.d.i Current/future solutions that can enable development-compatible emissions reduction in this country (in line with the SDGs)}

\section{Agriculture and Livestock/ Land use and Natural Resources:}

Agroecology: Brazil is a leading country in advancing the agroecological production. Agroecology is a form of agricultural production based on 13 elements: 1) recycling; 2) input reduction; 3) soil health; 4) animal health; 5) biodiversity; 6) synergy; 7) economic diversification; 8) co-creation of knowledge; 9) social values and diets; 10) fairness; 11) connectivity; 12) land and natural resource governance; 13) participation ${ }^{193}$. Brazil currently has a network of agroecological movements and farmer cooperatives, but funding for research and credit to make an agroecological system is currently lacking ${ }^{194}$. However, agroecological production offers an existing and future solution for both climate change adaptation, mitigation and a net zero transition ${ }^{195}$. Each of the 13 elements of agroecology are based on the productive capacity of small to medium producers who present locally-adaptive systems, with the co-creation of knowledge for future innovation. Supporting resource-restricted farmers also has the dual benefit of poverty reduction (SDG1) and ending hunger (SDG2).

Food Sovereignty: The food sovereignty movement is based on "the right of peoples to healthy and culturally appropriate food produced through ecologically sound and sustainable methods, and their right to define their own food and agriculture systems"196. It can serve as a complementary governance framework to agroecology. Whereas agroecology is primarily concerned with the production of food, food sovereignty is a platform to engage the population in democratising the food system. In Brazil, the current legal framework of the "right to food" already presents a governance platform to enact future solutions around food sovereignty on a national level ${ }^{197}$. However, the "right to food" in Brazil is currently limited in its institutional reach to enact more broad-based and localised citizen participation in the design of food systems. Food sovereignty presents a framework to support ending hunger (SDG2) and good health and well-being (SDG3).

\section{Physical infrastructure:}

Water and sanitation: Nearly half of Brazilians don't have access to sewage systems of treatment. This shortcoming is especially pronounced in urban areas and favelas. Sustainable water and sanitation systems would help support the more efficient use and recycling of water in the country. The country has a current average water loss rate of $37 \%$ due to leakages, poor management and theft ${ }^{198}$. The current and future solutions include: water capture and collection; improved water storage; water treatment; ecological restoration and management. The Northeast region of Brazil also presents opportunities for expanding the existing effort to build water cisterns for rural populations. This region's vulnerability to drought means that cisterns can provide residents with the opportunity to build resilience by collecting and storing water ${ }^{199}$. These solutions contribute to combatting poverty (SDG1), ending hunger (SDG2), good health and well-being (SDG3) and clean water and sanitation (SDG4). 
Other current and future solutions in physical infrastructure include: green bonds for financing low carbon transport; expansion of digital communication networks; inter and intra city rail; 'green' buildings and green belt initiatives. A 'greener' transportation network could help to decrease Brazil's imports of gasoline and diesel, as well as limit the production of monoculture biofuels such as sugar cane and corn.

Energy generation: Brazil's energy sector is one of the lowest emitters of GHG amongst major countries. The reliance on hydroelectric sources does present some risks under current climate scenarios. Therefore, some current and future solutions include: reservoir-based hydroelectric; local stakeholder participation in all energy projects; socially-inclusive solar in the Northeast region; expansion of wind farms in the Northeast region; Bioenergy with Carbon Capture and Storage (BECCS) ${ }^{200}$. One of the challenges with BECCS in Brazil is that a majority of the biomass produced in the country comes from large-scale industrial agriculture. There are both social and environmental trade-offs with the BECCS model. Therefore, a just transition involving BECCS would also likely involve a suite of public policies, including an enforceable Forest Code, cash transfers and research and development into permaculture biomass production ${ }^{201}$. All of the current and future solutions for energy generation contribute to combatting poverty (SDG1), good health and well-being (SDG3) and clean water and sanitation (SDG6).

\section{3.e Likely co-benefits and trade-offs of the solutions and opportunities identified, including, where relevant, in the context of the Sustainable Development Goals}

Agriculture and livestock/Land-use and natural resources: These two sectors have numerous co-benefits and trade-offs. The co-benefits are clearest when looking at solutions to deforestation. Land-use changes away from large-scale agribusiness and livestock and towards ecosystem services will reduce deforestation and result in multipliers for better environmental and climatic conditions for the agriculture and livestock sector ${ }^{202}$. Additionally, a focus on more sustainable production methods, such as agroecology, would have benefits for human health, food security and poverty reduction ${ }^{203}$. An important trade-off is the potential economic risks of transitioning away from export-led agricultural growth, and especially key global commodities (i.e. soybeans, beef, coffee, corn) and towards more diverse production ${ }^{204}$. A potential benefit would be more high-value crops and the potential to capitalize on increased dietary diversity within the domestic market ${ }^{205}$. The circular and bioeconomy can provide inclusive growth opportunities for Indigenous and traditional peoples as well as growth for scientific innovation.

Physical infrastructure: Improved access to and efficient use of water and sanitation will have co-benefits with other sectors, such as agriculture, livestock and energy generation. A low-carbon transport network will also reduce car and truck travel that can improve congestion, especially in major urban centres, and result in better air quality for human health and agricultural production. More integration between population centers can provide economic opportunities and more efficient transportation of goods and services.

Energy generation: More sustainable and renewable energy sources will further improve air quality and have the opportunity to lower prices if complemented with 
developments in the electric grid. For the Northeast, in particular, the installation of wind and solar generation units could provide an additional source of employment for residents, and a source of technological innovation for energy companies and the public sector.

\section{Definitions of key terms}

Mitigation The lessening of the potential adverse impacts of physical hazards through actions that reduce hazard, exposure, and vulnerability.

Adaptation The process of adjustment to actual or expected climate and its effects, in order to moderate harm or exploit beneficial opportunities.

Resilience The ability of a system and its component parts to anticipate, absorb, accommodate or re- cover from the effects of a hazardous event in a timely and efficient manner while retaining the same basic structure and ways of functioning, the capacity for self-organization and the capacity to adapt to stress and change.

Vulnerability The degree to which a system is susceptible to, or unable to cope with, adverse effects of climate change, including climate variability and extremes.

Risk The potential for consequences where something of value is at stake and where the outcome is uncertain, recognizing the diversity of values. Risk is often represented as probability or likelihood of occurrence of hazardous events or trends multiplied by the impacts if these events or trends occur.

\section{Acknowledgments}

This country profile was written by Dr Ryan Nehring (University of Cambridge, UK), with the input from in-country academic experts Dr. Roberto Luís de Melo Monte-Mór (Federal University of Minas Gerais, Brazil), Dr. Jakob Sparn (Federal University of Minas Gerais, Brazil), Dr. Olinda Canhoto (Centro de Biotecnologia Amazônia, Brazil) and Dr. Carlos Lamarão (Federal University of Amazonas, Brazil), in the context of the BEIS COP26 Futures We Want project. The production of the document was supported by project teams at Cambridge Zero (University of Cambridge) and Deloitte. The authors thank Dr Andrew Hartley (Met Office, UK) for his review, which significantly improved the quality of this manuscript. 


\section{References}

\footnotetext{
${ }^{1}$ Hemming, J. (1987). Amazon frontier : the defeat of the Brazilian Indians. Cambridge, Mass.: Harvard University Press.

2 Hemming, John. (1978). Red gold : the conquest of the Brazilian Indians. London: Macmillan.

3 Silva Junior, Celso H.L. et al. (2020) "The Brazilian Amazon Deforestation rate in 2020 is the Greatest of the Decade" Nature Ecology \& Evolution 5: 144-145.

${ }^{4}$ Kröger, Markus (2020) "Field Research Notes on Amazon Deforestation During the Bolsonaro Era" Globalizations 17(6): 1080-180-83

${ }^{5}$ PInho, Carlos Eduardo Santos (2021) "Welfare State and Epistemic Communities of Fiscal Austerity in Brazil: From Lula da Silva to Jair Bolsonaro (2003-2020)"

Sociedade e Estado 36(1).

6 Hargreaves, Peter (2008) "Phytosociology in Brazil" The Americas Journal of Plant Science and Biotechnology 2(2).

7 CEPEA/ESALQ "PIB do Agronegócio Brasileiro" Link

8 This includes electricity, household cooking fuel, water, waste and waste management.

${ }^{9}$ IBGE, First trimester 2021 GDP data (accessed from personal contact) 10
}

World Bank Data Bank - Jobs, Brazil Link

11 World Bank. N.d. "The World Bank in Brazil" Link

12 USDA (2020) "Brazilian Agricultural Sector Thrives Despite COVID-19 Pandemic" USDA - Foreign Agricultural Service Link

${ }^{13}$ CEIC. N.d. "Brazil's Automotive Sector Poised for Strong Growth" Link

14 https://www.rigzone.com/training/heavyoil/insight.asp?i id=192

${ }_{15}$ United Nations Development Programme (2020) Human Development Profile for Brazil Link

16 Valadares, Alexandre Arbex, Fernando Gaiger Silveira and Nikolas de Camargo Pirani (2017) "Human development and land tenure in Brazil" IPC-IG Working Paper No. 154 Link

17 Ipea and FJP (2020) Atlas do Desenvolvimento Humano no Brasil Link

18 World Bank (2019) Gini Index (World Bank Estimate) - Brazil Link

19 Albertus, Michael, Thomas Brambor and Ricardo Ceneviva (2016) "Land Inequality and Rural Unrest: Theory and Evidence from Brazil" Journal of Conflict Resolution 62(3): 557-596.

20 Imaflora "Atlas - The Geography of Brazilian

21 The term "family farm" in Brazil is a legal definition that refers to any agricultural establishment that: 1) must generate a majority of its income from the establishment; 2)owned and operated by a family; 3) utilizes the family's labour as the primary source of labour on the farm; 4) an area of less than 4 fiscal modules (the size of a fiscal module is determined by municipalities Link

22 IBGE. "Censo Agropecuário 2017" Rio de Janeiro: IBGE.

23 West, Thales A.P., Jan Börner and Philip M. Fearnside (2019) Climatic Benefits from the 1006-2017 Avoided Deforestation in Amazonian Brazil, Frontiers in Forests and Global Change 2(52).

24 Ioris, Antonio Augusto Rossotto (2018) "Interrogating the Advance of Agribusiness in the Amazon: Production, Rent and Politics" Revista NERA 21(42): 74-97. 
${ }^{25}$ Rajão, Raoni et al. (2020) "The Rotten Apples of Brazil's Agribusiness" Science 369(6501): 246-248.

${ }^{26}$ Ribeiro, Milton Cezar et al. (2011) "The Brazilian Atlantic Forest: A Shrinking Biodiversity Hotspot" Biodiversity Hotspots: 405-434.

${ }^{27}$ Metzger, Jean Paul. (2009) "Conservation Issues in the Brazilian Atlantic Forest" Biological Conservation 142: 1138-1140.

${ }^{28}$ Fearnside, Philip M. (1990) "Fire in the Tropical Rain Forests of the Amazon Basin" in Goldammer, J.G. (ed.) Fires in the Tropical Biota: Ecosystem Processes and Global Challenges, Heidelberg, Germany: Springer-Verlag, pp. 106-116.

${ }^{29}$ Arruda, Daniel, Rúbia Fonseca and Hugo Galvão Candido (2019) "Amazon Fires Threaten Brazil's Agribusiness" Science 365(6460): 1387.

${ }^{30}$ Fonseca-Morello, Thiago et al. (2017) "Fires in the Brazilian Amazon: Why does Policy have a Limited Impact?" Ambiente \& Sociedade XX(4): 19-38.

${ }^{31}$ Ferreira de Souza, Pedro H.G. (2018) "A History of Inequality: Top Incomes in Brazil, 1926-2015" IPC-IG Working Paper No. 167 Link

${ }^{32}$ Góes, Carlos and Izabela Karpowicz (2017) "Inequality in Brazil: A Regional Perspective" IMF Working Paper No. 17/225 Link

${ }^{33}$ IPAM (2012) "O Programa 'Agricultura de Baixo Carbono' do Brasil: Barreiras para sua Implementação" Instituto de Pesquisa Ambiental da Amazônia

${ }^{34}$ Damasio, Kevin (2020) "Emissões de Gases Estufa Aumentam no Brasil -

Atividades Rurais Lideram" National Geographic Brasil Link

Qin, Yuanwei et al. (2021) "Carbon Loss from Forest Degradation Exceeds that from Deforestation in the Brazilian Amazon" Nature Climate Change 11: 442-448.

${ }^{36}$ Silva, Claudia Arantes, Giancarlo Santilli, Edson Eyji Sano and Giovanni Laneve (2021) "Fire Occrances and Greenhouse Gas Emissions from Desforestation in the Brazilian Amazon" Remote Sensing 13(376).

${ }^{37}$ Magrin, G.O., J.A. Marengo, J.-P. Boulanger, M.S. Buckeridge, E. Castellanos, G. Poveda, F.R. Scarano, and S. Vicuña (2014) "Central and South America" in: Climate Change 2014: Impacts, Adaptation, and Vulnerability. Part B: Regional Aspects. Contribution of Working Group II to the Fifth Assessment Report of the Intergovernmental Panel on Climate Change Barros, V.R., C.B. Field, D.J. Dokken, M.D. Mastrandrea, K.J. Mach, T.E. Bilir, M. Chatterjee, K.L. Ebi, Y.O. Estrada, R.C. Genova, B. Girma, E.S. Kissel, A.N. Levy, S. MacCracken, P.R. Mastrandrea, and L.L. White (eds.) Cambridge University Press, Cambridge, United Kingdom and New York, NY, USA, pp. 1499-1566.

${ }^{38}$ Béllard, C., Leclerc, C., Leroy, B., Bakkenes, M., Veloz, S., Thuiller, W., et al. (2014) "Vulnerability of biodiversity hotspots to global change" Global Ecology and Biogeography, 23, 1376-1386.

${ }^{39}$ Strassburg, B. B. N., Brooks, T., Feltran-Barbieri, R., Iribarrem, A., Crouzeilles, R., Loyola, R., et al. (2017). "Moment of truth for the Cerrado hotspot" Nature Ecology and Evolution, 1, 0099.

${ }^{40}$ Magrin, G. O., Marengo, J. A., Boulanger, J.-P., Buckeridge, M. S., Castellanos, E., Poveda, G., et al. (2014). "Central and South America" In V. R. Barros, C. B. Field, D. J. Dokken, M. D. Mastrandrea, K. J. Mach, T. E. Bilir, M. Chatterjee, K. L. Ebi, Y. O. Estrada, R. C. Genova, B. Girma, E. S. Kissel, A. N. Levy, S. MacCracken, P. R. Mastrandrea, \& L. L. White (Eds.), Climate change 2014: Impacts, adaptation, and vulnerability. Part B: Regional aspects. Contribution of working group II to the 
fifth assessment report of the intergovernmental panel on climate change Cambridge, UK: Cambridge University Press, pp. 1499-1566.

41 Staal, A., B.M. Flores, A.P D Aguari, J.H.C. Bosmans, I. Fetzer \& O.A.

Tuinenburg. (2020). "Feedback between Drought and Deforestation in the Amazon"

Environmental Research Letters 15.

42 Tabarelli, M., Leal, I. R., Scarano, F. R., \& Silva, J. M. C. (2017). "The future of the Caatinga" In S. JMC, I. R. Leal, \& M. Tabarelli (Eds.), Caatinga Cham, Switzerland: Springer, pp. 461-474.

${ }^{43}$ Deloitte "Brazilian Energy Matrix: The Evolution of Energy Resources in Brazil" Link 44 Dias, Viviane de Souza, Marta Pereira da Luz, Gabriela M. Medeiro and Diego Tarley Ferreira Nascimento (2018) "An Overview of Hydropower Reservoirs in Brazil: Current Situation, Future Perspectives and Impacts of Climate Change" Water 10(5): 1-18.

${ }^{45}$ Schaeffer, Roberto et al. "Climate Change and the Energy Sector in Brazil" in Nobre, Carlos A., Jose A. Marengo and Wagner R. Soares (eds.) Climate Change Risks in Brazil, Cham, Switzerland: Springer Nature, pp. 143-179.

${ }^{46}$ Sorribas, M. V., R. C. D. Paiva, J.M. Melack, J.M. Bravo, C. Jones, L. Carvalho, E. Beighley, B. Forsberg and M.H. Costa. (2016). "Projections of Climate Change Effects on Discharge and Inundation in the Amazon Basin" Climate Change 136: 555-570.

${ }^{47}$ Pereira de Lucena, A.F. et al. (2009). "The Vulnerability of Renewable Energy to Climate Change in Brazil" Energy Policy 37(3): 879-889.

48 Magrin, G.O., J.A. Marengo, J.-P. Boulanger, M.S. Buckeridge, E. Castellanos, G. Poveda, F.R. Scarano, and S. Vicuña (2014) "Central and South America" in: Climate Change 2014: Impacts, Adaptation, and Vulnerability. Part B: Regional Aspects. Contribution of Working Group II to the Fifth Assessment Report of the Intergovernmental Panel on Climate Change Barros, V.R., C.B. Field, D.J. Dokken, M.D. Mastrandrea, K.J. Mach, T.E. Bilir, M. Chatterjee, K.L. Ebi, Y.O. Estrada, R.C. Genova, B. Girma, E.S. Kissel, A.N. Levy, S. MacCracken, P.R. Mastrandrea, and L.L. White (eds.) Cambridge University Press, Cambridge, United Kingdom and New York, NY, USA, pp. 1499-1566.

${ }^{49}$ For example, in the extreme south of the country the seasons are more pronounced and subject to variation within them. In the Amazon, the seasonal change could be characterized as 'more rainy' and 'less rainy' as the region is overall high in humidity and subject to local variations in forest cover and the presence of bodies of water (i.e. the Amazon basin).

50 Avila-Diaz, Alvaro, Gabriel Abrahão, Flavio Justino, Roger Torres and Aaron Wilson (2020) "Extreme Climate Indices in Brazil: Evaluation of Downscaled Earth System Models at High Horizontal Resolution" Climate Dynamics 54: 5065-5088.

51 USAID Climate Risk Profile: Brazil Link

52 Meyer, Kyle et al. (2017) "Conversion of Amazon Rainforest to Agriculture Alters Community Traits of Methane-Cycling Organisms" Molecular Ecology 26: 1547-1556. 53 Leite-Filho, Argemiro T. et al. (2021) "Deforestation Reduces Rainfall and Agricultural Revenues in the Brazilian Amazon" Nature Communications 12(2591): 17.

${ }^{54}$ Nascimento, Leonardo L. and Jefferson R. de Quadros (2018) "Do Tempo do Direito ao Tempo dos Rios Voadores: As Águas da Amazônia à Margem da Lei” Revista de Direito Ambiental e Socioambientalismo 4(2): 124-145. 
55 Coe, Michael T. et al. (2017) "The Forests of the Amazon and Cerrado Moderate Regional Climate and Are the Key to the Future" Tropical Conservation Science 10: $1-6$.

56 Magrin, G.O., J.A. Marengo, J.-P. Boulanger, M.S. Buckeridge, E. Castellanos, G. Poveda, F.R. Scarano, and S. Vicuña (2014) "Central and South America" in: Climate Change 2014: Impacts, Adaptation, and Vulnerability. Part B: Regional Aspects. Contribution of Working Group II to the Fifth Assessment Report of the Intergovernmental Panel on Climate Change Barros, V.R., C.B. Field, D.J. Dokken, M.D. Mastrandrea, K.J. Mach, T.E. Bilir, M. Chatterjee, K.L. Ebi, Y.O. Estrada, R.C. Genova, B. Girma, E.S. Kissel, A.N. Levy, S. MacCracken, P.R. Mastrandrea, and L.L. White (eds.) Cambridge University Press, Cambridge, United Kingdom and New York, NY, USA, p. 1512.

57 USAID Climate Risk Profile: Brazil Link

58 Barbieri, Alisson F. et al. (2010) "Climate Change and Population Migration in Brazil's Northeast: Scenarios for 2025-2050" Population and Environment 31: 344370.

59 Francini-Filho, Ronaldo B. et al. (2018) Perspectives on the Great Amazon Reef: Extension, Biodiversity, and Threats" Frontiers in Marine Science 23.

${ }^{60}$ Ranasinghe, R., A. C. Ruane, R. Vautard, N. Arnell, E. Coppola, F. A. Cruz, S. Dessai, A. S. Islam, M. Rahimi, D. Ruiz Carrascal, J. Sillmann, M. B. Sylla, C. Tebaldi, W. Wang, R. Zaaboul, 2021, Climate Change Information for Regional Impact and for Risk Assessment. In: Climate Change 2021: The Physical Science Basis. Contribution of Working Group I to the Sixth Assessment Report of the Intergovernmental Panel on Climate Change [Masson-Delmotte, V., P. Zhai, A. Pirani, S. L. Connors, C. Péan, S. Berger, N. Caud, Y. Chen, L. Goldfarb, M. I. Gomis, M. Huang, K. Leitzell, E. Lonnoy, J. B. R. Matthews, T. K. Maycock, T. Waterfield, O. Yelekçi, R. Yu and B. Zhou (eds.)]. Cambridge University Press. ${ }^{61}$ Alves de Oliveira, B.F., M.J. Bottino, P. Nobre \& C. Nobre. (2021). "Deforestation and Climate Change are Projected to Increase Heat Stress Risk in the Brazilian Amazon" Communications Earth \& Environment 2: 207.

62 See: https://interactive-atlas.ipcc.ch/regionalinformation\#eyJ0eXBIljoiQVRMQVMiLCJjb21tb25zljp7ImxhdCI6OTc3MiwibG5nljo0 MDA2OTIsInpvb20iOjQsInByb2oiOiJFUFNHOjUOMDMwliwibW9kZSI6ImNvbXBsZX RIX2F0bGFzIn0sInByaW1hcnkiOnsic2NlbmFyaW8iOiJzc3A1ODUiLCJwZXJpb2QiOi Iyliwic2Vhc29uljoieWVhcilsImRhdGFzZXQiOiJDTUIQNilsInZhcmlhYmxllioidGFzliwi dmFsdWVUeXBIljoiQU5PTUFMWSIsImhhdGNoaW5nljoiU0INUExFliwicmVnaW9uU 2V0ljoiYXI2liwiYmFzZWxpbmUiOiJwcmVJbmR1c3RyaWFsliwicmVnaW9uc1NIbGVi dGVkljpbMTFdfSwicGxvdCl6eyJhY3RpdmVUYWliOiJwbHVtZSIsInNob3dpbmciOnR ydWUsIm1hc2siOiJub25Iliwic2NhdHRIcIINYWciOiJBTk9NQUxZliwic2NhdHRIcllWYX liOiJOYXMifX0=

${ }_{63}$ See Nobre, Carlos A., Jose A. Marengo and Wagner R. Soares (eds.) Climate Change Risks in Brazil, Cham, Switzerland: Springer Nature ${ }^{64}$ Ranasinghe, R., A. C. Ruane, R. Vautard, N. Arnell, E. Coppola, F. A. Cruz, S. Dessai, A. S. Islam, M. Rahimi, D. Ruiz Carrascal, J. Sillmann, M. B. Sylla, C. Tebaldi, W. Wang, R. Zaaboul, 2021, Climate Change Information for Regional Impact and for Risk Assessment. In: Climate Change 2021: The Physical Science Basis. Contribution of Working Group I to the Sixth Assessment Report of the Intergovernmental Panel on Climate Change [Masson-Delmotte, V., P. Zhai, A. 
Pirani, S. L. Connors, C. Péan, S. Berger, N. Caud, Y. Chen, L. Goldfarb, M. I. Gomis, M. Huang, K. Leitzell, E. Lonnoy, J. B. R. Matthews, T. K. Maycock, T. Waterfield, O. Yelekçi, R. Yu and B. Zhou (eds.)]. Cambridge University Press.

${ }^{65}$ Ranasinghe, R., A. C. Ruane, R. Vautard, N. Arnell, E. Coppola, F. A. Cruz, S. Dessai, A. S. Islam, M. Rahimi, D. Ruiz Carrascal, J. Sillmann, M. B. Sylla, C. Tebaldi, W. Wang, R. Zaaboul, 2021, Climate Change Information for Regional Impact and for Risk Assessment. In: Climate Change 2021: The Physical Science Basis. Contribution of Working Group I to the Sixth Assessment Report of the Intergovernmental Panel on Climate Change [Masson-Delmotte, V., P. Zhai, A. Pirani, S. L. Connors, C. Péan, S. Berger, N. Caud, Y. Chen, L. Goldfarb, M. I. Gomis, M. Huang, K. Leitzell, E. Lonnoy, J. B. R. Matthews, T. K. Maycock, T. Waterfield, O. Yelekçi, R. Yu and B. Zhou (eds.)]. Cambridge University Press.

${ }^{66}$ Marengo, Jose A. et al. 2019 "Increase Risk of Drought in the Semiarid Lands of Northeast Brazil due to Regional Warming above 4C" in Nobre, Carlos A., Jose A. Marengo and Wagner R. Soares (eds.) Climate Change Risks in Brazil, Cham, Switzerland: Springer Nature, pp. 181-200.

${ }^{67}$ Nobre, Carlos A., Jose A. Marengo and Wagner R. Soares (eds.) Climate Change Risks in Brazil, Cham, Switzerland: Springer Nature.

68 Alisson, Elton (2017) "Sea Levels Along the Brazilian Coast are Expected to Rise in Coming Decades" FAPESP, June 28 ${ }^{\text {th }}$, 2017, Available at: https://agencia.fapesp.br/sea-levels-along-the-brazilian-coast-are-expected-to-risein-coming-decades/25560/.

${ }^{69}$ Kissinger, G., M. Herold \& V. de Sy. (2012). "Drivers of Deforestation and Forest Degradation: A Synthesis Report for REDD+ Policymakers" Lexeme Consulting: Vancouver.

70 Rajão, Raoni et al. (2020) "The Rotten Apples of Brazil's Agribusiness" Science 369(6501): 246-248.

71 Scarano, Fabio Rubio and Paula Ceotto (2015) "Brazilian Atlantic Forest: Impact, Vulnerability, and Adaptation to Climate Change" Biodiversity Conservation 24: 23192331.

72 Dantas de Paula, Mateus, Cecília Patrícia Alves Costa and Marcelo Tabarelli (2011) "Carbon Storage in a Fragmented Landscape of Atlantic Forest: The Role Played by Edge-affected Habitats and Emergent Trees" Tropical Conservation Science 4(3): 349-358.

73 Wolford, Wendy (2010) This Land is Ours Now: Social Mobilization and the Meanings of Land in Brazil, Durham: Duke University Press.

74 Zanetti, Vitor Baccarin, Welson Cabral de Sousa Junior and Débora M. de Freitas (2016) "A Climate Change Vulnerability Index and Case Study in a Brazilian Coastal City" Sustainability 8(811): 1-12.

75 Martins, Karoline Angélica et al. (2018) "The Influence of Climate Change on Coastal Erosion Vulnerability in Northeast Brazil" Coastal Engineering Journal 59(2): $1-25$.

76 Rodrigo de Queiroz, Anderson et al. (2019) "Hydropower Revenues under the Threat of Climate Change in Brazil" Renewable Energy 133: 873-882. 
77 Pires, Gabrielle F. et al. (2016) "Increased Climate Risk in Brazilian Double Cropping Agriculture Systems: Implications for Land Use in Northern Brazil" Agricultural and Forest Meteorology 228-229: 286-298.

78 Assad, E. and H.S. Pinto (2008) Aquecimento Global e a Nova Geografia da Produção Agrícola no Brasil, Brasilia: Embrapa.

${ }^{79}$ Ribeiro, Suzana Kahn and Andrea Souza Santos (2016) "Mudanças Climáticas e Cidades: Relatório Especial do Painel Brasileiro de Mudanças Climáticas" Rio de Janeiro: PBMC, COPPE - UFRJ. Link

80 Patel, Dipa (2020) "'Environmental' Catastophes: An Overview of the Power Relations Behind the Mariana Dam Disaster in Brazil" London: LSE, available at: https://blogs.Ise.ac.uk/internationaldevelopment/2020/06/11/environmentalcatastrophes-an-overview-of-the-power-relations-behind-the-mariana-dam-disasterin-brazil/.

${ }^{81}$ Quaresma, Valéria et al. (2020) "The Effects of a Tailing Dam Failure on the Sedimentation of the Easter Brazilian Eastern Shelf' Continental Shelf Research 205 ${ }^{82}$ Rotta, Luiz Henrique Silva et al. (2020) "The 2019 Brumadinho Tailings Dam Collapse: Possible Cause and Impacts of the Worst Human and Environmental Disaster in Brazil" International Journal of Applied Earth Observation and Geoinformation 90.

${ }^{83}$ Government of Brazil (2021) "Desempenho do Setor Mineral em 2020 Supera Expectativas" Link

${ }^{84}$ Ministério de Minas e Energia (2013) "Plano Setorial de Mitigação e de Adaptação à Mudanca do Clima na Mineração" Plano de Mineração de Baixa Emissão de Carbono (Plano MBC) Link

${ }^{85}$ Figueiredo, Leopoldo G.G.G., Rafael Douglas Ribeiro Mourão, Thiago dos Santos and Gilberto Berzin (2016) O Porto de Santos e o Aumento do Nível do Mar: Um Desafio a ser Enfrentado" Leopoldianum 42: 177-202.

${ }^{86}$ Schaeffer, R. et al. (2019) "Climate Change and the Energy Sector in Brazil" in Nobre, C., J. Marengo and W. Soares (eds.) Climate Change Risks in Brazil, Cham, Switzerland: Springer.

87 PMBC (2016) Impacts, Vulnerabilities and Adaptation: Contribution of Working Group 2 to the First Assessment Report of the Painel Brasileiro de Mudanças Climáticas, Rio de Janeiro: PMDC Link

88 IBGE. 2007. Censo Agropecuário 2006 Rio de Janeiro: IBGE.

89 Silvério, Divino, Sonaira Silva, Ane Alencar and Paulo Moutinho (2019) "Technical note from the Amazon Environmental Research" IPAM.

${ }^{90}$ Magrin, G.O., J.A. Marengo, J.-P. Boulanger, M.S. Buckeridge, E. Castellanos, G. Poveda, F.R. Scarano, and S. Vicuña (2014) "Central and South America" in: Climate Change 2014: Impacts, Adaptation, and Vulnerability. Part B: Regional Aspects. Contribution of Working Group II to the Fifth Assessment Report of the Intergovernmental Panel on Climate Change Barros, V.R., C.B. Field, D.J. Dokken, M.D. Mastrandrea, K.J. Mach, T.E. Bilir, M. Chatterjee, K.L. Ebi, Y.O. Estrada, R.C. Genova, B. Girma, E.S. Kissel, A.N. Levy, S. MacCracken, P.R. Mastrandrea, and L.L. White (eds.) Cambridge University Press, Cambridge, United Kingdom and New York, NY, USA, pp. 1499-1566.

${ }^{91}$ Ribeiro, Suzana Kahn and Andrea Souza Santos (2016) "Mudanças Climáticas e Cidades: Relatório Especial do Painel Brasileiro de Mudanças Climáticas" Rio de Janeiro: PBMC, COPPE - UFRJ. Link 
92 Handam, Natasha Berendonk et al (2020) "Qualidade de Água para Consumo Humano em Favelas Urbanas Brasileiras" Revista Ambiente \& Água 15(3).

${ }^{93}$ PMBC (2016) Impacts, Vulnerabilities and Adaptation: Contribution of Working Group 2 to the First Assessment Report of the Painel Brasileiro de Mudanças Climáticas, Rio de Janeiro: PMDC Link

${ }^{94}$ Barbieri, Alisson F. et al. (2010) "Climate Change and Population Migration in Brazil's Northeast: Scenarios for 2025-2050" Population and Environment 31: 344370.

${ }_{95}$ Marengo, Jose A., Roger Rodrigues Torres and Lincoln Muniz Alves (2017) "Drought in Northeast Brazil - Past, Present, and Future" Theoretical and Applied Climatology 129: 1189-1200.

${ }_{96}$ Paixão, Marcelo, Irene Rossetto, Fabiane Montovanele and Luiz M. Carvano (2010) Relatório Anual das Desigualdades Raciais no Brazil, 2009-2010, Editora Garamond. ${ }^{97}$ Government of Brazil (2016) "Indígenas, Negros e Mulheres são mais afetados por pobreza e desemprego no Brasil, diz Cepal" Link

98 Skoufias, Emmanuel (ed.) (2012) The Poverty and Welfare Impacts of Climate Change: Quantifying the Effects, Identifying the Adaptation Strategies, Washington DC: The World Bank 99 IBGE. "Censo Agropecuário 2017" Rio de Janeiro: IBGE.

100 IBGE. "Censo Agropecuário 2017" Rio de Janeiro: IBGE.

101 Machado Filho, Haroldo, et al. (2016) "Mudança do Clima e os Impactos na Agricultura Familiar no Norte e Nordeste do Brasil" Working Paper No. 141, Brasilia: IPC-IG Link

102 Maia, Alexandre Gori, Jennifer Anne Burney, José Daniel Morales Martínez and Daniele Cesano (2021) "Improving Production and Quality of Life for Smallholder Farmers through a Climate Resilience Program: An Experience in the Brazilian Sertão" PLoS One 16(5).

103 UK Government n.d. "Continuous Cover Silviculture - What is a Silvicultural System? Available at: https://www.forestresearch.gov.uk/tools-andresources/fthr/resources-on-managing-resilient-forests/continuous-cover-silviculturewhat-is-a-silvicultural-system/

${ }_{104}$ Government of Brazil (2016) "Plano ABC - Agricultura de Baixa Emissão de Carbono" Link

${ }^{105}$ Embrapa (2020) "Mitigação das Emissões de Gases de Efeitos Estufa pela Adoção das Tecnologias do Plano ABC: Estimativas Parciais" Documentos 122, Brasilia: Embrapa.

${ }^{106}$ Embrapa (2020) "Mitigação das Emissões de Gases de Efeitos Estufa pela Adoção das Tecnologias do Plano ABC: Estimativas Parciais" Documentos 122, Brasilia: Embrapa

107 Ofstehage, Andrew and Ryan Nehring (2021) "No-till Agriculture and the Deception of Sustainability in Brazil" International Journal of Agricultural Sustainability

108 Vale, Petterson et al. (2019) "The Expansion of Intensive Beef Farming to the Brazilian Amazon" Global Environmental Change 57: 1-11.

109 Coe, Michael T. et al. (2017) "The Forests of the Amazon and Cerrado Moderate Regional Climate and Are the Key to the Future" Tropical Conservation Science 10: 1-6. 
110 Gianetti, Giovani William and Joaquim Bento de Souza Ferreira Filho (2021) "O Plano e Programa ABC: Uma Análise da Alocação dos Recursos" Revista de Economia e Sociologia Rural 59()1): 1-15. Link

111 Silva Junior, Celso H.L. et al. (2020) "The Brazilian Amazon Deforestation rate in 2020 is the Greatest of the Decade" Nature Ecology \& Evolution 5: 144-145.

112 Rajão, Raoni et al. (2020) "The Rotten Apples of Brazil's Agribusiness" Science 369(6501): 246-248.

113 Ministério de Minas e Energia (2013) "Plano Setorial de Mitigação e de Adaptação à Mudanca do Clima na Mineração" Plano de Mineração de Baixa Emissão de Carbono (Plano MBC) Link

114 Government of Brazil (2019) Brazil's Third Biennial Update Report to the United Nations Framework Convention on Climate Change, Brasilia: Ministry of Foreign Affairs.

115 Ministério da Ciência, Tecnologia e Inovações (2021) "Quarta Comunicação Nacional do Brasil à Convenção-Quadro das Nações Unidas sobre Mudança do Clima" Brasilia: Ministério da Ciência, Tecnologia e Inovações, Link

116 Diário Oficial da União (2021) "Resolução no. 3 de 9 de Abril de 2021" Link

117 Andrade, Maryane BT, Lucas Ferrante and Philip M. Fearnside. (2021) "Brazil's Highway BR-319 Demonstrates a Crucial Lack of Environmental Governance in Amazonia" Environmental Conservation February 2021.

118 Goldemberg, José (2018) "Energy in Brazil: Past and Future" in Amann, Edmund, Carlos R. Azzoni and Werner Baer (eds.) The Oxford Handbook of the Brazilian Economy, Oxford, UK: Oxford University Press.

119 Luomi, Mari (2014) "Sustainable Energy in Brazil: Reversing Past Achievements or Realizing Future Potential” OIES Paper SP34, Oxford Institute for Energy Studies Link 120 Santos, Inaiê Takaes (2020) "Confronting Governance Challenges of the Resource NExus through Reflexivity: A Cross-case Comparison of Biofuel Policies in Germany and Brazil" Energy Research \& Social Science 65.

121 Empresa de Pesquisa Energética (2018) "Mudanças Climáticas e Desdobramentos sobre os Estudos de Planejamento Energético: Considerações Iniciais" Link

122 The Global Network for Human Rights and the Environment (2020) "ADPF708/Climate Fund. What to Expect from Brazil's First Public Hearing on Climate Policy?" Link

123 Guimarães de Araújo, Suely Mara Vaz (2020) "Environmental Policy in the Bolsonaro Government: The Response of Environmentalists in the Legislative Arena" Brazilian Political Science Review 14(2).

124 Pereira, Eder J. de A. L. et al. (2019) "Policy in Brazil (2016-2019) Threaten Conservation of the Amazon Rainforest" Environmental Science and Policy 100: 8-12. 125 Pignati, Wanderlei Antonio et al. (2017) "Spatial Distribution of Pesticide use in Brazil: A Strategy for Health Surveillance" Ciência \& Saúde Coletiva 22(10).

126 IBGE. "Censo Agropecuário 2017" Rio de Janeiro: IBGE.

127 Araujo Pereira, Arthur P. de, et al. (2021) "Grazing Exclusion Regulates Bacterial Community in Highly Degraded Semiarid Soils from the Brazilian Caatinga Biome" Land Degradation \& Development 32(6): 2210-2225.

128 Meyer, Kyle et al. (2017) "Conversion of Amazon Rainforest to Agriculture Alters Community Traits of Methane-Cycling Organisms" Molecular Ecology 26: 1547-1556. 
129 Martorano, Lucieta G. et al. (2016) "Agriculture and Forest: A Sustainable Strategy in the Brazilian Amazon Australian Journal of Crop Science 10(8): 1136-1143.

130 Coe, Michael T. et al. (2017) "The Forests of the Amazon and Cerrado Moderate Regional Climate and Are the Key to the Future" Tropical Conservation Science 10: 1-6.

131 Azevedo, Andrea A., Maura Campanili and Cassio Pereira (eds.) Caminhos para uma Agricultura Familiar sob Bases Ecológicas: Produzindo com Baixa Emissão de Carbono, Belém: IPAM.

132 Clark, Alistair (2020) "Brazil" MST Guidance vs Bolsonaro's Irresponsibility" LAB, Latin America Bureau, available at: https://lab.org.uk/brazil-mst-guidance-vs-

bolsonaros-irresponsibility/.

${ }_{133}$ Azevedo, Andrea A. et al. (2017) "Limits of Brazil's Forest Code as a Means to End Illegal Deforestation" Proceedings of the National Academy of Science of the United States of America 114(29): 7653-7658.

134 Vieira, Raísa R.S., et al. (2017) "Compliance to Brazil's Forest Code will not Protect Biodiversity and Ecosystem Services" Diversity and Distributions: A Journal of Conservation Biogeography 24(4): 434-438.

135 Pereira, Felipe M. (2015) "'A Ousadia de Conviver com a Floresta': Uma Ecologia Política do Extrativism na Amazônia" PhD Thesis, Universidade de Coimbra.

136 Nehring, Ryan, Ana Miranda and Andrew Howe (2017) "Making the Case for Institutional Demand: Supporting Smallholders through Procurement and Food Assistance Programmes" Global Food Security 12: 96-102.

137 Alves, Wellington, Paula Ferreira and Madalena Araújo (2020) "Challenges and Pathways for Brazilian Mining Sustainability" Resources Policy

138 CEPAL (2015) "The Effects of Climate Change on the Coasts of Latin America and the Caribbean: Climate Variability, Dynamics and Trends" Santiago, Chile: CEPAL

139 Fatin, Leena (2020) "Brazilian Govt Announces First LATAM Green Bond Program to Fund Infrastructure Projects with Green Bonds - with Climate Bonds Certification" Climate Bonds Initiative, July $7^{\text {th }}, 2020$ Link

140 World Bank (2013) "Incorporating Disaster Risk Management in the Transport Sector in Brazil: Challenges and Opportunities" Working Paper No. 82542, Washington DC: The World Bank.

141 Ribeiro de Andrade, Amanda et al. (2021) "Wind Speed Trends and the Potential of Electricity Generation at New Wind Power Plants in Northeast Brazil" Journal of the Brazilian Society of Mechanical Sciences and Engineering 43.

142 Nobre, Paulo et al. (2019) "Solar Smart Grid as a Path to Economic Inclusion and Adaptation to Climate Change in the Brazilian Semiarid Northeast" International Journal of Climate Change Strategies and Management 11(4): 499-517.

143 Sousa, Kleber A. et al. (2016) "Bioeconomia na Amazônia: Uma Análise dos Segmentos de Fitoterápicos \& Fitocosméticos, sob a Perspectiva da Inovação" Fronteiras: Journal of Social, Technological and Environmental Science 5(3): 151-171. 144 Valli, Marilia, Helena M. Russo and Vanderlan S. Bolzani (2018) "The Potential Contribution of the Natural Products from Brazilian Biodiversity to Bioeconomy" Anais da Academia Brasileira de Ciências 90: 763-778.

145 Valli, Marilia and Vanderlan S. Bolzani (2019) "Natural Products: Perspectives and Challenges for Use of Brazilian Plant Species in the Bioeconomy" Anais da Academia Brasileira de Ciências 91 
146 Instituto Escolhas (2019) "A New Economy for the Amazonas: Manaus Free Trade Zone and Bioeconomy" Presentation

147 Bluevision-Braskem (2019) "Brazil's $1^{\text {st }}$ Waste-generated Energy Plant will be in Paraná" Link

148 Al Doory, Omar and Daniel Freytag (2019) "Developing Waste-to-Energy in Brazil: A Pre-feasibility Study for a Waste-to-Energy Plant in Santa Catarina, Brazil" Thesis for the School of Engineering in Jönköping.

149 Girardin, Cécile A.J. et al. (2021) "Nature-based Solutions can Help Cool the Planet - If We Act now" Nature 593: 191-194.

150 Seddon, Nathalie et al. (2020) "Getting the Message Right on Nature-based Solutions to Climate Change" Global Change Biology 27: 1518-1546.

151 Suedel, B.C., Amorim, R.S., T.J. Lauth \& C.T. Creech. (2021). "Nature-based

Solutions for Improving Navigation Reliability on the Madeira River, Brazil" Integrated Environmental Assessment and Management, early view.

152 Diniz, Sibelle Cornélio (2016) "Do Precário ao Plural: Realidade e Possibilidades da Economia Popular no Brazil Contemporâneo" PhD Thesis, Universidade Federal de Minas Gerais.

153 Morais, Leandro Pereira and Miguel Juan Bacic (2020) "Social and Solidarity Economy and the Need for its Entrepreneuring Ecosystem: Current Challenges in Brazil" Revista de Economía Pública, Social y Cooperativa 98: 5-30.

154 Kawano, Emily (2020) "Solidarity Economy: Building na Economy for People and Planet" in Gustave Speth, James and Kathleen Courrier (eds.) The New Systems Reader: Alternatives to a Failed Economy, New York and London: Routledge, pp. 285302.

155 Esteves, Ana Margarida et al. (2021) "Sustainable Entrepreneurship and the Sustainable Development Goals: Community-led Initiatives, the Social Solidarity Economy and Commons Ecologies" Business Strategy and the Environment 30(3): 1423-1435.

156 Otsuki, Kei and Fabio de Castro (2019) "Solidarity Economy in Brazil: Towards Institutionalization of Sharing and Agroecological Practices" in Saito, Osamu (ed.) Sharing Ecosystem Services: Building More Sustainable and Resillient Society, Cham, Switzerland: Springer, pp. 159-178.

157 IPAM (2012) “O Programa 'Agricultura de Baixo Carbono' do Brasil: Barreiras para sua Implementação" Instituto de Pesquisa Ambiental da Amazônia

158 Francesco de Maria, Pier (2019) "Pobreza e Migração no Brasil Metropolitano (1995-2015)" Revista Brasileira de Estudos Urbanos e Regionais 21(3)

159 Amaral de Andrade, Roberta, Mario Socomano Neto and Silvio Eduardo Alvarez Candido. (2021) "Implementing Community-Based Forest Management in the Brazilian Amazon Rainforest: A Strategic Action Fields Perspective" Environmental Politics.

160 Yanai, Aurora Miho et al. (2020) "Deforestation Dynamics in Brazil's Amazonian Settlements: Effects of Land-Tenure Concentration" Journal of Environmental Management 268.

161 Ministério de Saúde (2011) Índice de GINI da Renda Domiciliar Per Capita - Brasil Link

162 IBGE (2011) Sinopse do Censo Demográfico: 2010, Rio de Janeiro: IBGE. Link 163 Neri, Marcelo (2013) "The New Brazilian middle Class and the Bright Side of the Poor" Policy in Focus No. 26, Brasilia: IPC-IG. 
164 https://www.extraclasse.org.br/economia/2021/02/aumento-do-custo-de-vida-temmaior-impacto-na-populacao-de-baixa-renda/

165 Ribeiro, Marcelo (2021) "Salles diz que orçamento para Meio Ambiente está 'fragilizado' e que corte começou em 2013" Valor Económico 3 April, 2021 Link

166 Pinto, Julian Torres de Miranda et al. (2018) "Road-rail Intermodal Freight Transport as a Strategy for Climate Change Mitigation" Environmental Development 25: 100-110.

167 Herwehe, Lauren and Christopher A. Scott (2017) "Drought Adaptation and Development: Small-scale Irrigated Agriculture in Northeast Brazil" Climate and Development 10(4): 337-346.

168 Gobetti, Sérgio Wulff and Rodrigo Octávio Orair (2017) "Taxation and Distribution of Income in Brazil: New Evidence from Personal Income Tax Data" Brazilian Journal of Political Economy 37(2): 267-286.

169 Jorio, Ado et al. (2010) "Brazilian Science Towards a Phase Transition" Nature Materials 9: 528-531.

170 Sousa Santos, Boaventure de (1998) "Participatory Budgeting in Porto Alegre: Toward a Redistributive Democracy" Politics \& Society 26(4): 461-510.

171 Leão, Marília and Ranato S. Maluf (2012) "Effective Public Policies and Active Citizenship: Brazil's Experience of Building a Food and Nutrition Security System", Brasilia: ABRANDH. Link

172 Stratton, A.E., H. Wittman and J. Blesh (2021) "Diversification Supports Farm Income and Improved Working Conditions During Agroecological Conditions" 41(3): $1-22$.

173 Ricciardi, V. et al. (2021) "Higher Yields and More Biodiversity on Smaller Farms" Nature Sustainability Link

174 Coasta, Francisco de Assis (2020) "Economia Camponesa Referida ao Bioma da Amazônia: Atores, Territórios e Atributos" Paper do Naea 1(2).

175 Wolford, Wendy (2010) This Land is Ours Now: Social Mobilization and the Meanings of Land in Brazil, Durham: Duke University Press.

176 Ronchi, Silvia and Andrea Arcidiacono (2019) "Adopting an Ecosystem ServicesBased Approach for Flod Resilient Strategies: The Case of Rocinha Favela (Brazil)" Sustainability 11(1).

177 Tagomori, Isabela S. et al. (2018) "Designing an Optimum Carbon Capture and Transportation Network by Integrating Ethanol Distilleries with Fossil-fuel Processing Plants in Brazil" Control 68: 112-127.

178 Rajão, Raoni et al. (2020) "The Rotten Apples of Brazil's Agribusiness" Science 369(6501): 246-248.

179 IBGE (2020) Censo Agropecuário 2017, Rio de Janeiro: IBGE.

180 Xilli, Marcia et al. (2020) "The Impact of Climate Change on Brazil's Agriculture" Science and the Total Environment 740.

${ }^{181}$ Carvalho, N.B. et al. (2020) "How Likely is Brazil to Achieve its NDC Commitments in the Energy Sector? A Review on Brazilian Low-Carbon Energy Perspectives" Renewable and Sustainable Energy Reviews.

182 Van Soest, Heleen L., Michel G.J. de Elzen and Detlef P. van Vuuren (2021) "Netzero Emission Targets for Major Emitting Countries Consistent with the Paris Agreement" Nature 12(2140): 1-9. 
183 Fórum Brasileiro de Mudança do Clima (2018) "Brasil Carbono Zero em 2060" Relatório do Fórum Brasileiro de Mudança do Clima para a Presidência da República.

184 https://www.power-technology.com/news/industry-news/brazil-net-zero-australiaiceland-climate-emissions-goals/

185 Greenpeace, Imaflora, Imazon, Instituto Centro de Vida, Instituto Socioambiental, IPAM, The Nature Conservancy and WWF (2017) "A Pathway to Zero Deforestation in the Brazilian Amazon" Link

186 Amigo, Ignacio (2020) "When will the Amazon hit a Tipping Point?" Nature 578: 505-507.

187 Pereira, Eder Johnson de Area Leão et al. (2020) "Brazilian Policy and Agribusiness Damage the Amazon Rainforest" Land Use Policy 92.

188 IBGE (2020) "Censo Agropecuário 2017" Rio de Janeiro: IBGE.

189 Rajão, Raoni et al. 2020 "The Rotten Apples of Brazil's Agribusiness" Science 369(6501): 246-248.

190 Odell, Scott D., Anthony Bebbington and Karen E. Frey (2018) "Mining and Climate Change: A Review and Framework for Analysis" The Extractive Industries and Society 5(1): 201-214.

191 Filho, José Di Bella (2020) "Market Analysis - Port Sector" Report Commissioned by the Netherlands Enterprise Agency.

192 Araujo, Maria de Penha S., Vânia Barcellos G. Campos and Renata Albergaria M. Bandeira (2013) "Na Overview of Road Cargo Transport in Brazil" Transporte de Carga. Link

193 Wezel, Alexander et al. (2020) "Agroecological Principles and Elements and their Implications for Transitioning to Sustainable Food Systems: A Review" Agronomy for Sustainable Development 40.

194 Sambuichi, Regina Helena Rosa et al. (eds.) (2017) A Política Nacional de Agroecologia e Produção Orgânica no Brasil: Uma Trajetória de Luta pelo Desenvolvimento Rural Sustentável, Brasilia: Ipea.

195 Altieri, Miguel A. et al. (2015) "Agroecology and the Design of Climate ChangeResilient Farming Systems" Agronomy for Sustainable Development 35.

196 Via Campesina. "Declaration of Nyéléni" Link

197 Santarelli, Mariana, Luciana Marques Vieira and Jennifer Constantine (2018) "Learning from Brazil's Food and Nutrition Security Policies" Institute of Development Studies/Food Foundation Link

198 IDB (2018) "Opportunities for Sustainable Infrastructure Investments at City Level in Brazil” Link

199 J-pal (2014) "Harvesting Rainfall: Experimental Evidence from Cistern Deployment in Northeast Brazil" Link

200 Hickman, Leo (2016) "The History of BECCS" Carbon Brief Link

201 Moreira, José Roberto et al. (2016) "BECCS Potential in Brazil: Achieving Negative Emissions in Ethanol and Electricity Production based on Sugar Cane Bagasse and Other Residues" Applied Energy 171(1): 55-63.

202 Martorano, Lucieta G. et al. (2016) "Agriculture and Forest: A Sustainable Strategy in the Brazilian Amazon Australian Journal of Crop Science 10(8): 1136-1143. ${ }^{203}$ Altieri, Miguel A. et al. (2015) "Agroecology and the Design of Climate ChangeResilient Farming Systems" Agronomy for Sustainable Development 35. 
${ }^{204}$ Azevedo, Andrea A., Maura Campanili and Cassio Pereira (eds.) Caminhos para uma Agricultura Familiar sob Bases Ecológicas: Produzindo com Baixa Emissão de Carbono, Belém: IPAM.

${ }^{205}$ Nehring, Ryan, Ana Miranda and Andrew Howe (2017) "Making the Case for Institutional Demand: Supporting Smallholders through Procurement and Food Assistance Programmes" Global Food Security 12: 96-102 